Review

\title{
Food Addiction and Binge Eating: Lessons Learned from Animal Models
}

\author{
Marta G. Novelle * (D) and Carlos Diéguez * \\ Department of Physiology, Center for Research in Molecular Medicine and Chronic Diseases (CIMUS), \\ University of Santiago de Compostela-Instituto de Investigación Sanitaria (IDIS), CIBER Fisiopatología de la \\ Obesidad y Nutrición (CIBERobn), Instituto de Salud Carlos III, 15786 Santiago de Compostela, Spain \\ * Correspondence: marta.garrido@usc.es (M.G.N.); carlos.dieguez@usc.es (C.D.); Tel.: +34-647-344-282 (C.D.)
}

Received: 27 November 2017; Accepted: 9 January 2018; Published: 11 January 2018

\begin{abstract}
The feeding process is required for basic life, influenced by environment cues and tightly regulated according to demands of the internal milieu by regulatory brain circuits. Although eating behaviour cannot be considered "addictive" under normal circumstances, people can become "addicted" to this behaviour, similarly to how some people are addicted to drugs. The symptoms, cravings and causes of "eating addiction" are remarkably similar to those experienced by drug addicts, and both drug-seeking behaviour as eating addiction share the same neural pathways. However, while the drug addiction process has been highly characterised, eating addiction is a nascent field. In fact, there is still a great controversy over the concept of "food addiction". This review aims to summarize the most relevant animal models of "eating addictive behaviour", emphasising binge eating disorder, that could help us to understand the neurobiological mechanisms hidden under this behaviour, and to improve the psychotherapy and pharmacological treatment in patients suffering from these pathologies.
\end{abstract}

Keywords: eating addiction; opioids; dopamine; obesity; binge eating; animal models

\section{Introduction}

Eating disorders (ED), defined as disturbances in eating habits characterised by insufficient or excessive food intake causing energy imbalance, are associated with high comorbidity and have serious health consequences. Therefore, although the prevalence for ED has remained stable, the high mortality rate, the association with other psychiatric disorders, and an increased level of awareness of eating disorders between the general population and clinicians have encouraged researchers to investigate the genetic, neurochemical, and physiological substrates implicated in ED [1,2]. In a highly obesogenic environment, much attention has been given to ED characterised by compulsivity and overeating, including binge eating disorder (BED), certain forms of obesity, and the newly proposed construct of "food eating addiction" [3]. Throughout this review we will briefly cover current knowledge of the neurobiology of feeding behaviour, focusing on non-homeostatic circuits, and we will look over the controversy about the misconception of "food addiction". Finally, we will explore new evidences learned from animal models in order to get a better understanding of BED, recently integrated as a novel diagnosis into the Diagnostic and Statistical Manual of Mental Disorders (DSM-5).

\section{Understanding the Neurobiology of Eating Behaviour. Eating beyond Metabolic Needs}

Food intake is an essential behaviour for survival and highly regulated by homeostatic, hedonic and learned cues. Consequently, eating behaviour depends on a simultaneous functioning of homeostatic pathway together with a more flexible non-homeostatic one, whose functions can vary between individuals according to previous experiences and/or epigenetic variations [4-8]. 
New insights argue that the impact of the modern food environment is mainly on cortico-limbic brain systems dealing with reward, emotion and cognition. Signals from the cognitive and rewarding brain may override classic homeostatic regulation leading to development of obesity or eating disorders. These stimuli follow pathways that include, but are not limited to, corticolimbic regions within the amygdala, hippocampus, and thalamus; mesostriatal dopamine (DA)-gated circuits within the nucleus accumbens (NAc) and the ventral tegmental area (VTA); and prefrontal cortex (PFC) regions predominantly within the orbitofrontal projections [9-12].

In this context, Berridge and collaborators described three aspects of reward: liking, wanting, and learning, that despite being tightly linked they can be dissociable in terms of their neural substrates yet. So, while liking and wanting, respectively, refer to the hedonic impact of and the motivation for a reward, the learning process comprises the associations with and predictions about rewards [13,14]. Animal models have mainly associated opioid, cannabinoid, orexin and $\gamma$-aminobutyric acid (GABA) systems as mediators in the "liking" experience, via coordinated activity in a network of hedonic hotspots in the nucleus accumbens, ventral pallidum and brainstem. Moreover, these neurotransmitters can be also implicated in other processes of the reward regulation, as opioids enhancing the "wanting" [15]. On the other hand, the mesolimbic dopamine system is crucial in the "wanting" and "learning" components $[13,16]$. It should be pointed out that "liking" and "wanting" systems are essentially pure "go" systems. That means, once they are activated cannot be diminished by satiety influences, they never generate a strong "stop" signal to halt intake, they only tone down the intensity of the "go" [17]. Interestingly, the incentive sensitization theory of addiction proposed by Robinson and Berridge, is based on a pathological incentive motivation (wanting) for drugs even after the discontinuation of drug use, that can be manifest in behaviour via either implicit (as unconscious wanting) or explicit (as conscious craving) processes, depending on circumstances. These features are linked with learning mechanisms that normally direct motivation to specific and appropriate targets [18-20]. Likewise, excessive "wanting" and "liking" for food, notably hyper-palatable food, may play a role in overeating. Moreover, as in in drug dependence, the attractive and rewarding properties of hyper-palatable foods do not remain confined to the reward itself. Reward-related cues, in this case food cues, can be attributed with excessive incentive salience and become signals that draw attention and trigger overconsumption [21]. In other words, the wanting of addiction is connected less with pleasure (liking foods), and more with the negative reinforcement created by their withdrawal. Consequently, wanting and craving high sugar and high sugar/high fat foods are more about trying to prevent the return of negative feelings $[22,23]$.

\subsection{The Role of Opioid System, More Than "Liking" Regulation}

'Liking' and 'disliking' of a food was determined by carefully observing the orofacial expressions of rats drinking caloric test solutions. The original idea to observe rats' facial expressions to measure how much pleasure (or aversion) they are getting from a given food was inspired by earlier human studies and later adapted for rodents [24-26].

As we already have commented above, endogenous opioid system is crucial in "liking" aspect of the reward process. Despite of opioids are involved in a broadly distributed neural network, affecting both homeostatic and hedonic mechanisms; the dominant view is that opioids, especially the mu-opioid system, regulate the "hedonics of feeding" by their modulation of the palatability of food regardless of the caloric value presented. Opioids stimulated ingestion of "attractive" diets in sated rats, enhanced the "dessert effect" when a palatable food was offered at the end of a regular meal [27]. On the other hand, opioid antagonists attenuate appetite for palatable food. Thus, craving for palatable food could be considered as a form of opioid-related addiction [28,29].

All these conclusions are largely based on evidence obtained from animal models. Some studies tried to elucidate if opioids stimulate intake of specific macronutrients or of preferred foods. Several works showed that when rats could select the macro composition of the diets, after an injection of morphine, a $\mu$-opioid receptor agonist, animals had higher preference for fat intake, instead of 
carbohydrate intake [30], in contrast, the opioid antagonist, naloxone preferentially decreased fat intake [31]. According to these data, opioids regulate the intake of specific macronutrients. However, when the baseline dietary preferences of the rats were considered, after morphine injections, it was observed that opioidergic modulation of feeding may be driven more by individual preference than by macronutrient, since morphine primarily stimulated carbohydrate intake in the carbohydrate-preferers, and stimulated fat intake in the fat-preferers [32]. Glass et al. reported a complementary result with naloxone injections: the intake of the preferred diet was reduced by naloxone at lower doses than those required to reduce intake of the less-preferred diet [33]. Lately, it was observed that the opioid effects of preferred versus non-preferred food were dependent on the site of injection. Therefore, while the naltrexone (NTX, preferential $\mu$-opioid receptor antagonist) injections in the central nucleus of the amygdala caused a decrease in intake of the preferred food, injections in the paraventricular nucleus of hypothalamus caused a decrease in the intake of both foods [34]. The role of $\mu$-opioid stimulation is not only region-dependent. While $\mu$-opioid stimulation via microinjection of DAMGO ( $\mu$-agonist) within the rostrodorsal quadrant of NAc medial shell can double the hedonic impact of sweet tastes, stimulation in other sub regions of medial shell does not increase "liking" reactions to sweet food $[35,36]$. Finally, it should be noted that hedonic enhancement is also receptor (mu, delta, kappa) dependent [37]; although $\mu$ - and k-opioid receptor stimulation increased the 'liking', only the $\mu$-opioid receptor stimulation increased the incentive motivation for food [38]. Other researchers also provided some evidence of the role of opioid system either macronutrient or preference-specific effects on food intake. These studies showed that nucleus accumbens opioidergic effects were influenced by the relative preference for specific foods, foods high in fat or sugar. When both high-fat and high-sugar foods were available simultaneously, opioid stimulation increased intake more for the high-fat food [39-41]. However, Mena and collaborators showed that intra-PFC $\mu$-receptor stimulation augments the reward valuation of carbohydrate-enriched foods, along with several behavioural changes such as a high-arousal and stress-like state. The authors suggest that this carbohydrate hyperphagia could represent an attempt to suppress a stress-like aversive state, since PFC is significantly activated by stress [42]. One mechanism that could explained the opioid-mediated overconsumption of palatable foods is through delaying the satiety systems; either the melanocortin or oxytocin systems [27]. These preferences and craving for appetizing foods were also observed in several human studies [43-46].

Beyond "liking" process, opioid stimulation directly causes increased cue-triggered 'wanting' as well as dopamine stimulation. Therefore, opioid mechanisms can also regulate incentive motivational, to wit propensity to seek palatable foods $[37,38,47]$. In fact, for example, the injection of non-selective opioid receptor antagonist, nalmefene, blocked the anticipatory negative contrast in the binge-eating procedure as well as highly palatable food binge eating [48]. External food-related cues, learned cues, can also precipitate the desire for food, increasing the food craving independently of homeostatic needs. In this context, using Pavlovian-instrumental transfer (PIT) paradigm, that can model mechanisms responsible for producing "cue-triggered wanting" or craving [49], it was shown that opioid stimulation caused "wanting" as well as dopamine [47]. Additionally, NTX, and GSK1521498 ( $\mu$-opioid receptor antagonist) were tested on food seeking behaviour using chocolate-flavoured pellet reinforcement. Both compounds reduced food intake, but only GSK1521498 reduced the seeking responses for chocolate before ingestion, suggesting that $\mu$-opioid system has a crucial role on incentive motivational mechanisms controlling food seeking [50]. Noteworthy, the same compound also reduced motivational responding in binge-eating obese people in a placebo-controlled trial, although subjective liking increased following drug treatment [51]. It has been hypothesized that $\mu$-opioid receptors localized on the GABAergic interneurons in the VTA may act to decrease dopamine release in the NAc to reduce food seeking and incentive motivation for food [38,52].

Additional studies have also confirmed the role of opioid systems in other brain structures in the motivational mechanisms underlying eating behaviour. Therefore, when central amygdala (CeA) was stimulated by DAMGO infusions ( $\mu$-opioid agonist) caused elevated incentive motivation in subjects 
naturally attracted both by a predictive cue (sign-trackers) and by a reward contiguous goal cue (goal-trackers); also, an increase in "wanting" behaviour under PIT model [53,54]. On the other hand, likewise, $\mu$-opioid receptors within the medial prefrontal cortex (mPFC) mediate an important function in overeating. In fact, naltrexone microinfused into the $\mathrm{MPFC}$ selectively reduced the consumption and the motivation to obtain highly palatable food, but not standard chow [55], while intra-PFC DAMGO engendered "high-drive-like" effects [56]. In this context, Baldo group has suggested that neuroadaptations of the opioid system in MPFC could explain partly the development of binge-like eating $[42,57,58]$. Such as it has been recently demonstrated, mPFC exerts top-down control over midbrain dopaminergic interactions with the striatum and an increase in the $\mathrm{MPFC}$ can suppress natural reward-related behaviour [59]. Finally, it has been also reported that $\delta$-opioid receptors in the NAc-Shell are involved in the effects of predictive learning on choice between actions. In fact, under a PIT paradigm, the treatment with $\delta$-opioid receptor antagonist naltrindole, blocked this behaviour $[60,61]$.

\subsection{Dopamine System, the "Want" Pathway}

The association between dopamine and food intake appears to date from ancient times and it has been postulated to be linked to and play a key role in human evolution. Specifically, it was proposed that that increased levels of dopamine were part of a general physiological adaptation of our ancestors due to an increased consumption of meat around two million years ago and later enhanced by further changes in macronutrient intake about 80,000 years ago [62]. At present there are clear evidences that dopamine pathways and dopamine receptors are involved in energy homeostasis. In fact, there are clear evidences linking all the five subtypes dopamine-receptors to energy balance and metabolic homeostasis. In this regard the FDA have approved a D2-agonist, bromocriptine, as adjunctive treatment for type 2 diabetes [63]. Moreover, most of all the FDA-approved antiobesity drugs, including liraglutide, appears to act largely through dopaminergic pathways [64]. On the contrary chronic consumption of dopamine antagonists as in patients with schizophrenia leads to enhanced eating and weight gain. In general, the relevance of dopamine in the integrated control of the homeostatic pathways involved in food intake is beyond any doubt. Detailed studies on dopamine involvement in leptin- and ghrelin-elicited changes in food intake are well established [65]. This dopamine effects appear to be mediated by both D1R and D2R, being the latest one the most relevant. Moreover, heteromers of GHSR1:DRD2 have been implicated in obsessive eating associated to Prader-Willi Syndrome [66].

Another property inherently relevant to feeding behaviour is the concept regarding to reinforcement, motivation and incentive salience [67-70]. While "liking" is closer to sensory processes, "wanting" is closer to decision making and motor action, by reflecting the cue-driven inclination to choose one behaviour over another to optimize reward. Dopaminergic projections from the VTA to the NAc and prefrontal cortex are the most important component of the implicit or unconscious "wanting" system [71]. Part of dopamine hypothesis of reward is based on the initial work conducted by Wise and collaborators, where animals subjected to DA antagonist pimozide (specially D2 receptor) showed a decrease in self-stimulation in ways that implied a devaluation of reward, a decrease in the pleasure of the reinforcer [72,73]. Through the years many other groups have arrived at same conclusions, DA is required for normal motivation and reward, and has a crucial role in feeding behaviour; in fact, animals lacking dopamine throughout the brain and body do not eat $[74,75]$, although as it has been confirmed its role is brain-region dependent.

The NAc is a brain region in the ventral striatum that appears to play a crucial role in behaviours related to natural reinforcers and incentive as well as initiating key intracellular plasticity mechanisms required for learning about food resources [76,77]. Moreover, dopamine dynamics differ substantially between the NAc core and NAc shell in relation to distinct aspects of appetitive and aversive motivational states [78]. Pharmacological blockade of D1 and D2 dopamine receptors in the NAc affects motor conduct and has small effects on feeding patterns, but does not reduce the amount of 
food consumed. These effects can be interpreted as reflecting a more selective role for dopamine transmission in the anticipatory/approach phase versus the consummatory phase of feeding [79]. According to this idea, Salamone and colleagues carried out several interesting studies examining in deep the behavioural effects of moderate NAc dopamine depletions. They found that dopamine depletion reduced the motor effort to obtain food reward, but approach or intake did not decrease when food was clearly available [80-82], and still animals can have hedonic responses for food in the absence of dopamine [83]. Therefore, dopamine system would be responsive to reward predictors and seemingly unresponsive to the reward "itself" $[73,84]$. Nevertheless, restoring dopamine signalling selectively to the dorsal striatum, composed of the caudate and putamen, is sufficient to allow feeding, locomotion, and reward-based learning [85]. Besides, an increase of D2 receptors in the striatum are correlated with an optimal goal-directed behaviours and motivation [86,87].

In this context, the downregulation of striatal dopamine D2 function has been proposed to explain the reward deficiency or reward hyposensitivity theory [88]. According to this, a reduced D2R expression in the striatum, observed both in human and animal models, is a neuroadaptive response in order to compensate the overconsumption of palatable foods [89-92]. Furthermore, this reduced sensitivity potentially could predict a cause of excessive eating and/or obesity $[89,90,92,93]$. Consistent with the reward deficiency theory, some studies reported obese versus lean adults show lower striatal DA D2-like receptor availability [94,95], moreover obese adults have less capacity of nigrostriatal neurons to synthesize DA [96] and less striatal responsivity to tastes of high-fat/sugar beverages [97]. Also, patients with BED tend to have reduced level of DA in the brain [98]. Contrarily, other groups have shown higher striatal DA in obese individuals $[77,99]$. Despite some discrepancies regarding to striatal dopaminergic levels, the A1 allele of the D2/ANKK1 Taq1 polymorphism has been correlated with reduced D2R availability in the striatum, obesity and compulsive behaviour [77,100]. Likewise, D2 receptors were reported to provide a target for ameliorating binge eating behaviour in a rat model after NAc deep brain stimulation [101,102]. Therefore, while DA receptor 2 antagonism in NAc increases binge-like feeding [101], activation of serotonin 2C receptors in DA neurons inhibits this binge behaviour in mice [103].

It is important to note that in addition to its role in motivational processes, cortico-mesolimbic dopamine pathway also play an important role in mediating learning [14,104,105]. Changes in learning pathways might change rewarded responses. Learning processes are highly influenced by emotional and motivational components and required for reward prediction, for making anticipatory responses, for guidance by cues, and for goal-directed action. These cues from the environment, such as the sight and smell of food, or even advertisements for food, are learned and become associated with future reward [11,14]. A range of animal studies has demonstrated that food-associated cues can promote eating in the absence of metabolic requirements [106,107]. Thus, food-predictive cues can stimulate eating in adults and children, even when they are full $[6,108]$. The basis of cue-potentiated feeding (CPF) behaviour is Pavlovian conditioning. A feature of CPF is that it tends to be specific for the cued food and does not increase intake generally, which has similarities with the "cravings" experienced by binge eaters [109]. Recent studies have shown that dopamine has a selective role in stimulus-reward learning that is specifically associated with the attribution of incentive salience to reward cues. This fact could explain as individuals who attribute reward cues with incentive salience find it more difficult to resist such cues, a feature associated with reduced impulse control [110].

The mPFC receives information about cues in the environment via the sensory cortices, but also about the internal motivation to eat via dopamine neurones of the VTA [56,58]. A group of mPFC neurons, which contain the dopamine D1R receptors, are activated during hunger-induced food intake, and their stimulation and inhibition, increases and reduces feeding respectively. The main target of the D1R-containing subset of MPFC neurones is the medial BLA [111]. On the other hand, it has been hypothesised that the transition from voluntary drug use to more habitual and compulsive drug use represents a transition at the neural level from PFC to striatum; and a progression in the striatum from ventral to more dorsal domains, involving its dopaminergic innervation [112]. Moreover, reduced 
dopaminergic modulation has been suggested to impair inhibitory control over food intake and to increase risk of overeating in humans [95].

\subsection{Are There Other Neurotransmitters or Hormones That Can Modify "Liking" and/or "Wanting" Behaviours?}

In addition to the endogenous dopamine and opioid systems, various hormonal and neuropeptide systems influence performance in one or more of the food motivation behavioural paradigms described earlier. Signals such as leptin, insulin, ghrelin, glucagon-like peptide-1 (GLP-1) and melanin concentrating-hormone $(\mathrm{MCH})$, orexins, oxytocin, serotonin between others, are involved in hunger and satiety signalling as well as reward-related neurocircuitry. The review of this topic is complex and beyond the aim of this paper, but detailed reviews of this topic can be found elsewhere [113-123].

\section{Can We Talk about "Food Addiction"?}

The concept of food addiction has been suggested for the first time by Randolph in 1956 [124], but only recently it has received due attention, mainly because of its correlation to the increasing rate of obesity. "Addiction is defined as a chronic, relapsing brain disease that is characterised by compulsive drug seeking and use, regardless of unhealthy consequences" [125]. This chronic relapsing disorder is comprised of three steps: preoccupation/anticipation (craving), binge/intoxication, and withdrawal/negative effect. These three stages interact with each other, becoming more intense, and eventually leading to the pathological state known as addiction. Not all drugs produce the same pattern of addiction, but lately the progression of this behaviour triggers alterations in normal brain function and consequently induces neuroplasticity in all the structures implicated [22,23,126,127]. Remarkably, addiction induces neuronal changes in prefrontal cortical and basal ganglia activities, leading to reductions in control and decision-making skills, and causes a chronic perturbation in brain reward homeostasis mainly in the mesolimbic dopamine system. Moreover, the opioid, GABAergic and glutamatergic neurocircuitries play a key role in the development of addiction $[92,128,129]$.

In the context of environments saturated with food, where clearly, obesity has become a worldwide problem in a short time, and the binge eating disease is the eating disorder with more incidence $[130,131]$ several questions have been put forward. Can overeating become a pathologic attachment to food? If so, can clinicians and researchers assert that food addiction is a new category of psychiatric disorder or brain disease? Compulsive sexual behaviour, pathologic gambling, and hedonic overeating are important problems, but are they addictions?

Although in some cases excessive consumption of food can fit with all DSM-required criteria according to some, food addiction was not included in newest edition of the of the DSM manual [132]. Although it can share some symptoms with BED and obesity, and includes behavioural patterns similarly to substance use disorders [129]. One fundamental distinction between currently accepted addictive substances and food is the fact that food is necessary for survival. Notably, there is a still an ongoing debate between the scientific community about whether food addiction is a misnomer and the phenomenon could be more accurately categorised by an alternative designation [92,129,133-141]. Therefore, while some researchers see overeating as substance use disorders, where people are addicted to sugar, salt, additives and high fat content [140,142,143]; other suggest increased food intake related to obesity or eating disorders should be considered as a behavioural addiction $[136,144,145]$. Different views on this topic are almost unavoidable if we accept that it is quite unlikely that any animal model of food addiction can mimicked to a large extent food/eating addiction in humans. However, some researchers have tried to study the food addiction in animals by following the three-criteria model proposed by Deroche-Gamonet et al. [146]. Tolerance, reduction in the effect of a drug resulting from of repeated exposure to the substance, was observed after extended access to a palatable diet [147] and also some data suggest that there is a cross-tolerance between sweet solutions and opioids [148]. In this context, Woods hypothesizes humans must learn to tolerate the intake of food in order to minimize its impact on the body, as they learn responses to help them tolerate the administration of dangerous drugs [149]. Regarding to the withdrawal component of addiction, negative effects 
after the abrupt discontinuation or decrease in intake of drugs, conflicting results have been reported depending on the kind of food. This is discussed below in Section 4.1.3. Many other aspects related to "food addition" concept have been studied in animal models too. By using a so-called time-out model Ghizta and colleagues have attempted to elucidate the difficulty to limit intake or food seeking; after prolonged training, animals exposed to palatable diet increase their food seeking responses [150]. Moreover, some studies have demonstrated that animals continue to seek the food despite adverse consequences [89,151].

For the first time, the DSM-5 grouped a disorder not involving substance use (gambling disorder) together with substance use disorders in a new category entitled: "Substance Related and Addictive Disorders" [132]. In this context, our group agreed to other researchers, and based on the current studies, consider that there is no enough evidence to conclude that a specific food, food ingredient or food additive can be addictive. Although is too early to draw definitive conclusions regarding the "food addiction" concept and further work is necessary, we consider that we should talk about "eating addiction" or more precise "addictive eating behaviour" [136,152]. In agreement with other authors [153], we believe that some animal models from drug addiction research, as the three-criteria model [146], should be applied in eating disorder field. These models may provide us new neuronal mechanisms in order to elucidate differences between "food addiction" and other compulsive eating behaviours.

\section{Binge Eating Disorder, a "Full-Fledged" Pathology}

The newest edition of the Diagnostic and Statistical Manual of Mental Disorders (DSM-5) has introduced important changes in the diagnostic system for eating disorders; trying to improve the ability for clinicians to arrive at a precise diagnosis [132]. Perhaps the most significant improvement with the DSM-5 is that Binge Eating Disorder (BED) is now considered as proper diagnosis in parallel to other main eating disorders as Anorexia Nervosa and Bulimia Nervosa [154]. BED is the most prevalent eating disorder (between $2-5 \%$ of the adult population) and more common in women than men. BED is characterised by compulsive episodes of disproportionate consumption of highly palatable foods together with a strong sense of loss of control. Binge-eating episodes are often accompanied by feelings of anxiety, shame, disgust and guilt, high risk of suicide, but they are not followed by compensatory purging behaviours. Although BED is often associated with obesity many BED patients have normal body weights [130]. Based on these characteristics this kind of behaviour could be described as an addiction-like behaviour; that is, an "eating addiction" [136]. However, despite of existing research suggests that there is an overlap between BED and the "eating addiction" neither all people with BED meet Yale Food Addiction Scale (YFAS) criteria for this addiction nor all people with eating addiction meet criteria for BED $[152,155,156]$. In this context, Hoebel's group has modelled in rodents all the aspects of food addiction; "Bingeing", "withdrawal", "craving" and "cross-sensitization" with drugs of abuse. These researches have reported that sugar has addictive properties similar to psychostimulants and opioids, and confirmed it is possible to talk about sugar addiction as a different disorder from BED [157-160].

Since BED is now considered as proper diagnosis, there is a renew interest on the animal models used in order to uncover the neurobiological basis of BED. Herein we will review the most relevant features of some of these models.

\subsection{Lessons Learned from Animal Models}

Animal models can provide invaluable insight for neurobiological disorder research, especially when the aetiology is well characterised or when there are potentially genes associated. Current animal models of BED can only provide some few characteristics of the human disease. These models cannot reproduce all social context that influence human eating behaviour; neither some psychological aspects, such as sense of lack of self-control, blame or guilt. Moreover, there is not really a consensus about the criteria an animal model should fulfil [161]. This is major drawback considering the existence of 
strong differences with some rodent strains, e.g., obesity-prone vs. diet-resistant, that could be at the root of some discrepancies. In addition, one of the main features of BED is the much higher incidence in females and at specific stages of life as adolescence. The fact that the precise correlation between age of laboratory rats and human is still a subject of debate and the generalized use of male rats are further limiting factors. Despite this, these models have contributed to the understanding of the eating disorders, mainly trying to elucidate the neurobiological mechanisms implicated.

Many of the results obtained from animal models of eating disorders have been already discussed throughout the different epigraphy of this article. Likewise, more in detail reviews about this topic have been written over the last years [129,162-170]. Therefore, we will look briefly the plausible role of the genetic and environment background, and the relevance of different dietary macronutrients used in BED models that have not been discussed yet. Finally, we will highlight the state of the art of new drugs for the treatment of BED.

\subsubsection{Genetic Factors}

Although the genetic study of BED is still in early stages and there are no enough genome-wide association studies (GWAS) focused exclusively on BED, preliminary evidences suggests that could there be predisposing risk factors [171-174]. In fact, there are good evidences that heritable factors make a significant contribution to the risk of developing eating disorders [175]. Patrono et al. showed that exposure to environmental conditions induces compulsion-like eating behaviour, depending on genetic background. Therefore, when they compared two mice inbred strains, C57BL/6J and DBA/2J, they observed that only DBA mice shift from motivated behaviour to compulsive eating behaviour. They hypothesised that this result could be explained as a genetic vulnerability (low accumbal D2 receptors availability observed in this study) [176]. This same year, the Bryant group has reported two genetic factors implicated in the development of BED in mice models. They observed that C57BL/6NJ but not C57BL/6J mice showed rapid and robust escalation in palatable food consumption and identified Cyfip2 (cytoplasmic FMR1-interacting protein 2) as a major genetic factor in preclinical BED; suggesting that could be associated with maladaptive feeding in humans. Based on the association of Cyfip1 with Prader-Willi syndrome, one hypothesis is that Cyfip1 polymorphisms also affect BED and hyperphagia [177]. At the same time, they showed Csnkle (casein kinase 1 epsilon) deletion increased binge eating behaviours by enhancing opioid-induced locomotor activity [178]. Moreover, these authors have also reported a robust strain difference in BED (C57BL/6J versus DBA/2J strain) in accordance with previous results. Therefore, D2J showed escalation in consumption, conditioned place preference for the food-paired side and compulsive-like eating in an anxiety-provoking environment relative to B6J [179]. In this same context, rat strain differences in binge eating proneness have been examined. Results showed that the Sprague-Dawley female strain is particularly vulnerable to binge eating behaviours, while the Wistar female rat strain is particularly resistant to BED. Moreover, Sprague-Dawley males showed low risk for binge eating too. Taken together these results highlight the key role of sex and genetic backgrounds in the propensity to binge eating behaviours [180]. Despite of oestradiol reduces meal size and is associated with reduced binge frequency, women are more likely to suffer from BED. In a fat binge eating animal model it was observed that ovarian hormones, oestradiol and progesterone, have a tonic inhibitory effect on food intake, but the normal cyclic inhibitory effect on eating was disrupted during binge-type eating episodes. This observation suggests that these inhibitory effects of oestradiol could be compromised by binge-type consumption of large fatty meals [181]. Concurrently, other study has reported that bingeing also attenuated oestradiol tonic effects. While both tonic and cyclic inhibition of chow intake was maintained after cyclic treatment of ovariectomised rats with oestradiol alone or co-administrated with progesterone, neither tonic nor cyclic inhibition of binge-type consumption was observed once bingeing was fully established [182]. Both studies indicate that oestrogens are the primary ovarian hormones responsible for food intake and body weight regulation under binge-type conditions in rats. The oestrogen metabolite, 2-hydroxyestradiol (2OHE2), has been hypothesised may enhance bingeing in rodent 
models due to its possible interference with DA signalling. In fact, 2OHE2 may competitively inhibit degradation of DA and/or mimic or enhance D2 receptor actions [183]. Corwin's group showed as chronic administration of 2OHE2 to ovariectomised female rats can exacerbate the induction of binge-type eating. Although they found that 2OHE2 attenuates the increase of food intake associated with ovariectomy, eating behaviour turns toward a binge-type pattern, when 2OHE2 is administrated before binge development and during all binge process. Therefore, this study suggests that chronic exposure to 2-hydroxyestradiol facilitates "learning to binge" [184]. The binge-eating proneness is also dependent on age. For both rat strains studied, Otsuka Long Evans Tokushima Fatty (OLETF) and lean control strain, Long Evans Tokushima Otsuka (LETO), the onset of binge eating behaviour was observed earlier in adolescents, with bigger binge size too. Higher impulsivity in adolescents could explain their increased vulnerability to BED and overeating. Furthermore, OLETF rats at both ages ate more than LETO rats. This is in accordance with the co-morbidity of BED and obesity reported in humans [185]. However, not always the binge eating behaviour is dependent on susceptibility to obesity, as animal models have confirmed $[186,187]$. The development of aberrant eating behaviour during adolescence has been also studied in other animal models (Sprague-Dawley strain). After postnatal treatment with tricyclic antidepressant clomipramine, female rats showed more vulnerability to exhibit binge-like eating behaviour during adolescence [188]. Sex differences in coping strategies with anxiety have been described clinically. Female strategy, more consistent with harm avoidance, has been associated with BED [189]. On the other hand, it has been proposed that cognitive deficits in executive function, inhibitory control, attention, and mental flexibility may play a role in development and sustaining of binge eating behaviour. When studying a limited access rat model of binge-like behaviour, Chawla et al. found aberrant gene expression of brain derived neurotrophic factor (BDNF) and tropomyosin receptor kinase B (TRKB) in the hippocampus (HPC)-prefrontal cortex (PFC) pathway. Moreover, they observed reductions in the expression of insulin receptor in the $\mathrm{CA} 3$ region of the hippocampus, up-regulation of serotonin-2C receptors in the orbitoprefrontal cortex and decreased dopamine receptor 2 expression in the nucleus accumbens (NAc). Altered expression of genes in the neural pathway HPC-PFC-NAc could be explained as consequence of engaging in the binge behaviour. Authors have also speculated that animals binge prone could have cognitive deficits and these contribute to their vulnerability [190]. Similar results were recently found in BED patients. Based on GWAS it has been possible to identify genes involved in neuropeptide/neurotrophic pathways including neurotensin, GLP1 and BDNF-TRKB signalling as potential therapeutic targets [191]. On the other hand, evidence of epigenetic modification affecting the N/OFQ (Nociceptin/Orphanin FQ) and corticotropin-releasing factor (CRF) systems in response to food restriction and stress exposure has been demonstrated. These mechanisms could be designed to maximize the possibility of survival in the presence of food restrictions, but in a society where nutrients are easily available, alteration of N/OFQ and CRF mechanisms may contribute to BED development [192].

\subsubsection{Environmental Factors}

Among the many environmental factors that can influence eating disorders together with the high palatable food availability, the high incidence of stress in western societies is probably one of the most relevant $[169,193]$. It is well documented with different animal models that stress can influence feeding behaviour [193-198] and increase the susceptibility to developing eating disorders [167]. Most of the animal models have focused the investigation on the regulation of the stress neurohormone corticotropin-releasing factor (CRF) system. Calvez et al. have found that stress differentially regulates brain expression of CRF in binge-like eating prone (BEP) and resistant (BER) female rats. Therefore, in response to stress, the BER rats significantly enhanced expression of CRF mRNA in the paraventricular nucleus of the hypothalamus and strongly increased the plasma corticosterone levels. Conversely, the BEP rats did not displayed stress-induced activation of the HPA axis, but they demonstrated high CRF mRNA expression in the oval and anteroventral bed nucleus of the stria terminalis (BNST), 
an important region for the motivated behaviour, in response to stress [199]. Moreover, BEP rats showed different behavioural and hormonal responses to stress. They showed higher motivation for palatable food and perceived hedonic value [200]. Function of BNST was also assessed in other models. Indeed, frustration stress manipulation increased BNST neuronal activity and CRF receptors of BNST seem to have a critical role in stress-induced binge eating disorder [201]. The role of other extra-hypothalamic CRF1 receptors, as those in central amygdala, has been also implicated in development of binge eating [202]. The early emotional environment also impacts on eating behaviour. Early attachment experiences increase the risk of eating disorders. In fact, the impact of perinatal programming on the mechanisms regulating body weight homeostasis has been fully studied [203]. This same year, an interesting work has shown that late gestation prenatal stress rewires neural circuits in female mice, leading to binge-like behaviour [204]. Authors reported that overexpression of maternal CRF, during late gestation affects the hypothalamus of female offspring, altering the expression levels of genes responsible for DNA methylation and predisposes adolescent female offspring to BE-like phenotype. Offspring with BE-like behaviour presented hypomethylation of hypothalamic miR-1a and downstream dysregulation of the melanocortin system through Pax7/Pax3. Finally, authors showed that although stress-related epigenetic predisposition can increase the vulnerability to BED, it can be prevented from being triggered with a methyl balanced diet during adolescence.

\subsubsection{Food Models: Sugar Model, Fat Model, Sweet-Fat Model}

The sugar bingeing model was proposed by Avena and collaborators [158,205]. This model uses sucrose, glucose and saccharin in different liquid solutions. After some days under this food animals modify the feeding behaviour and it is possible to induce neurochemical changes in the brain. Even, this model increases DA in NAc [206] and cessation of sweet food availability induces withdrawal-like behaviour [93,207]. Following withdrawal from ad libitum access to sugar diet, animals also showed depressive-like behaviour [208,209]. However, in a Wistar rat model of binge eating based on daily 10-min access to a sweet fat diet, there was no increased anxiety-like behaviour after diet withdrawal. In this same model, it was observed that pre-treatment with the cannabinoid type 1 receptor antagonist SR147778 dose-dependently reduced binge-like intake, while binge-like intake was unaffected by pre-treatment with the corticotropin-releasing factor type 1 receptor antagonist R121919 [210]. Sugar model has also been reported to increase the cross-sensitization with other substances [129,205]. Recently, it was observed as binge-like sucrose consumption reduces the dendritic length and complexity of principal neurons in basolateral amygdala (BLA) in an adolescent rat model. These maladaptive changes observed in dendritic architecture of BLA principal neurons, particularly on apical dendrites, show the importance of the BLA in encoding emotional salience [211]. Furthermore, sugar models have provided evidence of the relevance of dietary restraint as an antecedent to sugar binges, in concordance with human studies [212] and can reproduce one human feature of binge eating known as "eating when not physically hungry" [213]. The studies suggest that, as with sugar models, a similar addiction-like state may emerge with fat intake. Insight in this issue was obtained with the limited access model proposed by Corwin [214,215]. In this experimental paradigm, the rats are given sporadic (generally 3 times per week, binge group) or time-limited (daily access control group) access to palatable food, in addition to the continuously available chow. The palatable food typically is a bowl of pure vegetable shortening, but other palatable food can also be tested including sucrose solutions, various concentrations of fat presented as solid emulsions, high-fat diets, and fat/sucrose mixtures. In terms of neurochemical changes, it has been reported as binge eating of fat affects DA signalling in the accumbens and $\gamma$-aminobutyric acid (GABA ${ }_{B}$ ) receptors. In fact, licking of $100 \%$ corn oil increases DA and its metabolites in the NAc, similar to that seen in sugar-bingeing animals [216]. On the other hand, peripheral administration of the D2-like antagonist raclopride stimulated fat intake in intermittent-access rats and had no effect in daily-access rats. These results further implicate D2 receptors in the consumption of fatty food, but also indicate as well as uncover the role of differential pre- and post-synaptic D2 signalling under binge and control conditions [215,217]. 
In this same study, Corwin and colleagues have reported the role of $\mathrm{GABA}_{\mathrm{B}}$ receptors in fat binge eating models was studied. GABA ${ }_{B}$ agonist baclofen reduced intake of shortening, as well as high-fat solid emulsions, in rats with both daily and sporadic brief access at doses that stimulated or had no effect on chow intake $[217,218]$. However, baclofen did not have effect on intake of sugar solutions or when sugar concentration was high $[186,219,220]$. Corwin's model as well, has shown an increase in progressive-ratio responding in rats under binge eating fat, suggesting enhanced motivation [215]. Moreover, a history of fat bingeing may predispose to exhibit more robust addiction like behaviour to other abuse substances [221]. In contrast to sugar models, animals under fat bingeing models did not display withdrawal-associated symptoms [222], and even after several weeks fat-fed animals did not show significant changes in body weight, supporting the idea that BED and obesity are two different pathologies [129]. It has been proposed, that lack of opiate-like withdrawal signs in fat-bingeing rats may be caused by fat-induced endogenous galanin activation, which can inhibit the relevant opioid effects [163]. Finally, many studies have used a sweet-fat model ("cafeteria-diet"), which is probably the model most similar to the huge availability and diversity of foods that we have nowadays. According to sugar model, sweet-fat food also induced a downregulation of DA mesolimbic pathway [89]. Moreover, after exposure to cafeteria diet, following acute withdrawal animals showed increase in locomotor activity, stress and anxiety-related behaviour [207,208,223,224].

\subsubsection{Neuropharmacology of Binge-Eating Behaviour}

The treatment of binge eating disorder is challenging and require a big-picture treatment plan to meet the individual needs; combination of psychotherapy and medication is usually the best treatment strategy [130]. Oral lisdexamfetamine dimesylate (LDX), a prodrug of dextroamfetamine, is currently the only drug to be approved in the USA for the treatment of moderate to severe BED in adult patients [225]. When given acutely in a female rat BED model, LDX attenuated binge-eating of chocolate without influencing the consumption of normal chow or affecting the bodyweight of the animals [226] and reduced impulsiveness and perseverative behaviour of binge-eating rats in a novel food reward/punished responding conflict model [227,228]. Pharmacological characterisation indicated that LDX attenuates binge-eating in part by indirect activation of $\alpha 1$-adrenergic and possibly also dopamine D1 receptors in the CNS, but $\alpha 2$-adrenergic and D2 receptors are not involved [226]. Other novel pharmacological treatment approaches also give us additional information regarding the underlying neuro-pathways implicated in BED. For instance, the D2 receptor antagonist raclopride reduced sucrose intake [220]. Methylphenidate (MPH), which inhibits the monoamine uptake transporters for DA and norepinephrine, also reduces sucrose bingeing episodes in animal models. Concomitant with this, MPH treatment leads to increased DA transporter and D2 receptor binding in the NAc shell [229]. GS 455534, an aldehyde dehydrogenase-2 inhibitor that reduces DA synthesis has also been shown to selectively reduce binge consumption of sugar. Moreover, GS 455534 is associated with an attenuation of nucleus accumbens dopamine levels in sugar-bingeing rats model [230]. In addition, it was observed that monoamine stabilizer (-)-OSU6162, which restores striatal dopaminergic dysfunction, could be a novel BED treatment in rodent models since reduces both binge-like eating and cue-controlled food seeking in rats [231]. Selective serotonin reuptake inhibitors (SSRIs) have been also studied. Fluoxetine non-selectively reduced the intake of normal food and highly palatable food in a model of binge-eating that included cyclic caloric restriction and stress [232]. Moreover, it has been reported that fluoxetine and D-fenfluramine (a serotonin releasing agent) reduced binge-eating in mice on an intermittent high fat diet by enhancing midbrain dopamine neuronal activity [103]. Sibutramine, a monoamine reuptake inhibitor (MRI), removed from the worldwide market because of an increased risk of myocardial infarction and stroke, has been also studied in BED animal models [226,232], where reduced the binge eating behaviours. On the other hand, selective 5-HT2C receptor agonist lorcaserin, developed and approved as an anti-obesity agent, was recently shown to attenuate binge-eating in mice fed a high fat diet by stimulating dopamine neuronal activity [103]. In a recent study, it has been reported for the first 
time that trace amine-associated receptor-1(TAAR1) may represent a novel target for the treatment of BED. RO5256390, a TAAR1 partial agonist, completely blocked compulsive-like eating and conditioned rewarding properties of palatable food when studied in a rat model with limited access to a highly palatable sugar diet [233].

As we have already mentioned previously, the opioid system plays a key role in binge behaviours. In fact, opioid receptor antagonists, including naltrexone, nalmefene and GSK1521498 decreased both normal food intake and compulsive or excessive eating in several different binge-eating models in rats $[55,226,234]$. However, despite the positive pre-clinical evidences, placebo-controlled clinical studies in binge-eating disorder with opioid receptor antagonists have been disappointing [130].

The orexin system plays a role in eating disorders characterised by compulsive binge-type episodes, such as BED. For instance, in two different rat compulsive binge-eating models orexin receptor 1 (OXR1) antagonist SB-334867 and GSK1059865 specially reduced palatable versus normal food intake [226,235]. However, JNJ-10397049 a selective orexin receptor 2 (OXR2) antagonist, failed to affect the intake of palatable food and the dual OX1/OX2 receptor antagonist SB-649868 selectively reduced binge-eating of highly palatable food but did not affect the chow food pellet intake [235]. In this same context, it was observed that SB-334867, a selective OXR1 antagonist, decreased the binge-like consumption behaviour in an ad-lib feeding animal model [236].

The combination of pharmacological agents acting on different neural pathways may also provide novel therapy for BED. Modulation of GABAergic neural systems also represents a possible approach for BED treatment. Baclofen, a GABA $\mathrm{B}$ agonist, attenuated the intake of highly palatable food in several different animal models of binge-eating $[219,220,226,237]$. Recent studies have suggested Nociceptin/Orphanin FQ (N/OFQ) system, a functional antagonist of corticotrophin-releasing factor, as therapeutic target either obesity or BED. In fact, intracerebroventricular injections of N/OFQ at low doses significantly reduced BE in rats [238]. On the other hand, nociceptin receptor antagonist LY2940094 [239] and SB 612111 [240] inhibits excessive feeding behaviour in rodents. Interestingly, a novel drug for the treatment of BED, may be BD-1063, a selective sigma1 receptor antagonist. Although the selectivity of this compound has not been well characterised, BD-1063 blocked compulsive binge-eating in rats trained to obtain a sugary or highly palatable diet [241].

\section{Conclusions and Future Perspectives}

This review briefly presents the latest knowledge regarding the neurobiology of non-homeostatic pathways implicated in food intake regulation. Throughout the review we have tried to discuss the most relevant aspects that can help us to understand the dysregulation of brain reward systems in eating disorders, by focusing mainly on BED. However, me must be aware that in most instances it is far from clear whether the changes are related to the disease, consequence of altered homeostasis or a premorbid trait. During recent years, research in animal models of compulsive overeating has provided us essential knowledge to understand the neurobiology mechanisms underlying eating disorders, but there are still many features waiting to be elucidated. The main brain structures implicated are shown schematically in Figure 1. Among the mechanisms involved the role of dopamine appears clear-cut. Recent neuronal mapping using single-cell RNA-seq. have shown the existence of a higher diversity of neurones than originally expected with up to 62 neuronal subtypes producing glutamatergic, dopaminergic or GABAergic markers for synaptic neurotransmission having been identified. The challenge now is to associate the different subsets of neurones to specific neurobiological process and their alterations to specific disease-related process. After BED has been recognised as a proper psychiatric disorder, clinical and basic research in BED is in an exciting phase among other reasons because of the availability of new neuroimaging tools that allowed us to correlate basic neurobiological aspects to functionality in the human brain. Development of well-characterised models and new tools such as chemogenetics and optogenetics should provide us with a much better mechanistic insight and possible therapeutic targets for BED. Finally, we should not forget that any functional aspect of the brain is based on the complex interaction among many different neuronal 
pathways. It is expected that as soon as larger knowledge is gather from the connectome project [242] we will be in a much better position to tackle questions related to complex diseases such as BED and how nutrient intake, in terms of total amount and schedules, can influence cognitive process.

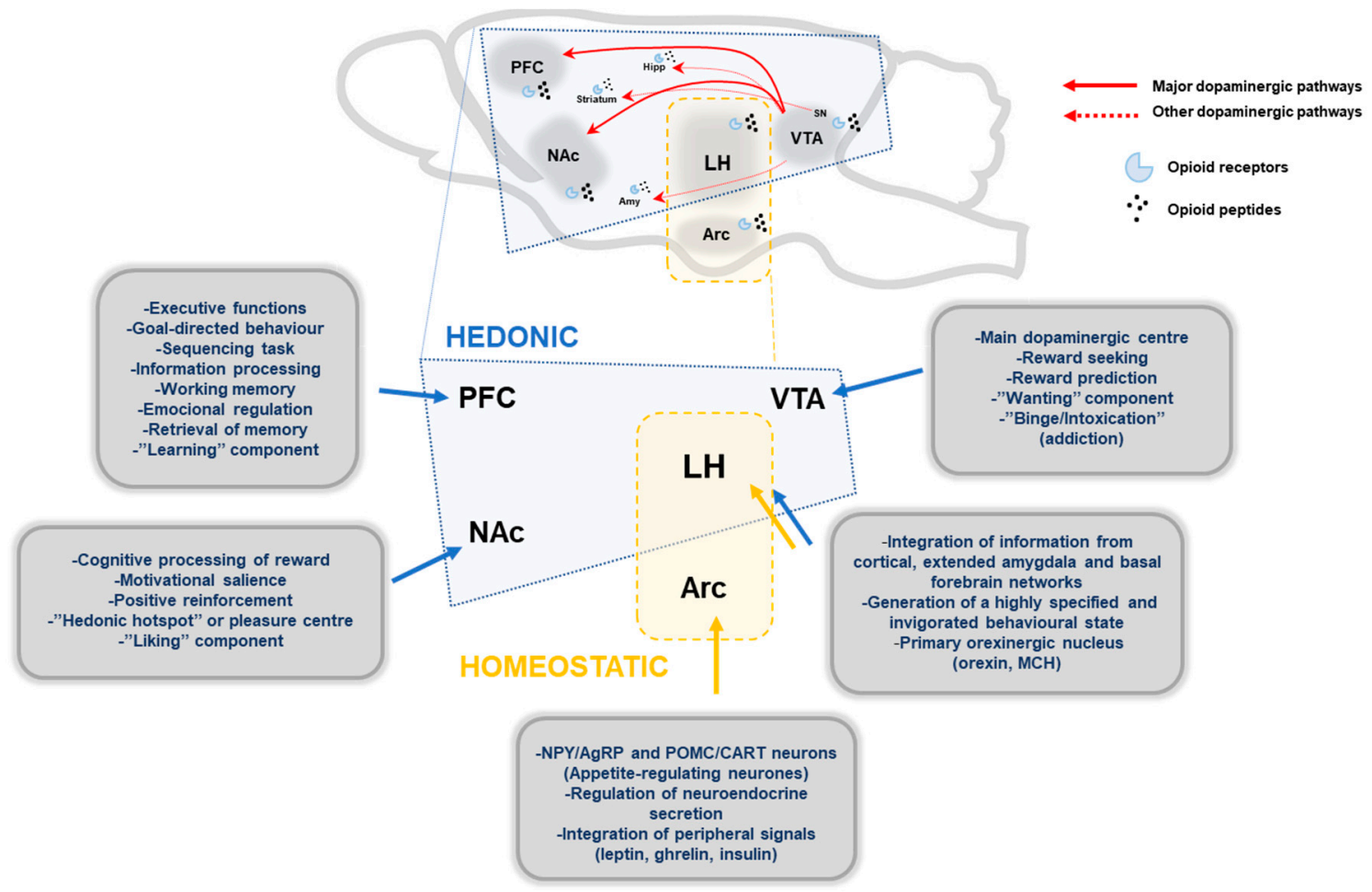

Figure 1. Schematic representation of main brain structures implicated in hedonic and homeostatic food intake regulation. Main dopaminergic pathways, mesolimbic and mesocortical pathway, are represented with red lines, and other minor dopaminergic connections with broken red lines. Endogenous opioids peptides modulate the dopaminergic pathways through opioid receptors $(\mu, \kappa, \delta)$. Hedonic pathways: PFC, prefrontal cortex; NAc, nucleus accumbens; VTA, ventral tegmentum area; LH, lateral hypothalamus; Amy, Amygdala; Hipp, Hippocampus; SN, substantia nigra. Homeostatic pathways: Arc, arcuate nucleus; $\mathrm{MCH}$, melanin concentrating-hormone.

Acknowledgments: This work has been supported by grants from Ministerio de Economía y Competitividad (CD BFU2014-55871), Xunta de Galicia (ED431, 2017/030). Centro de Investigación Biomédica en Red (CIBER) de Fisiopatología de la Obesidad y Nutrición (CIBERobn). CIBERobn is an initiative of the Instituto de Salud Carlos III (ISCIII) of Spain which is supported by FEDER funds.

Author Contributions: Both authors substantially contributed to the conception of the manuscript. M.G. Novelle and C. Diéguez contributed to the literature search and writing. Both revised and approved the final version.

Conflicts of Interest: The authors declare no conflict of interest.

\section{References}

1. Schaumberg, K.; Welch, E.; Breithaupt, L.; Hubel, C.; Baker, J.H.; Munn-Chernoff, M.A.; Yilmaz, Z.; Ehrlich, S.; Mustelin, L.; Ghaderi, A.; et al. The science behind the academy for eating disorders' nine truths about eating disorders. Eur. Eat. Disord. Rev. 2017, 25, 432-450. [CrossRef] [PubMed]

2. Smink, F.R.; van Hoeken, D.; Hoek, H.W. Epidemiology of eating disorders: Incidence, prevalence and mortality rates. Curr. Psychiatry Rep. 2012, 14, 406-414. [CrossRef] [PubMed]

3. Moore, C.F.; Sabino, V.; Koob, G.F.; Cottone, P. Pathological overeating: Emerging evidence for a compulsivity construct. Neuropsychopharmacology 2017, 42, 1375-1389. [CrossRef] [PubMed]

4. Yeo, G.S.; Heisler, L.K. Unraveling the brain regulation of appetite: Lessons from genetics. Nat. Neurosci. 2012, 15, 1343-1349. [CrossRef] [PubMed] 
5. DiLeone, R.J.; Taylor, J.R.; Picciotto, M.R. The drive to eat: Comparisons and distinctions between mechanisms of food reward and drug addiction. Nat. Neurosci. 2012, 15, 1330-1335. [CrossRef] [PubMed]

6. Johnson, A.W. Eating beyond metabolic need: How environmental cues influence feeding behavior. Trends Neurosci. 2013, 36, 101-109. [CrossRef] [PubMed]

7. Schneeberger, M.; Gomis, R.; Claret, M. Hypothalamic and brainstem neuronal circuits controlling homeostatic energy balance. J. Endocrinol. 2014, 220, T25-T46. [CrossRef] [PubMed]

8. Berthoud, H.R. The neurobiology of food intake in an obesogenic environment. Proc. Nutr. Soc. 2012, 71, 478-487. [CrossRef] [PubMed]

9. Berthoud, H.R. Interactions between the "cognitive" and "metabolic" brain in the control of food intake. Physiol. Behav. 2007, 91, 486-498. [CrossRef] [PubMed]

10. Berthoud, H.R.; Morrison, C. The brain, appetite, and obesity. Annu. Rev. Psychol. 2008, 59, 55-92. [CrossRef] [PubMed]

11. Higgs, S. Cognitive processing of food rewards. Appetite 2016, 104, 10-17. [CrossRef] [PubMed]

12. Meye, F.J.; Adan, R.A. Feelings about food: The ventral tegmental area in food reward and emotional eating. Trends Pharmacol. Sci. 2014, 35, 31-40. [CrossRef] [PubMed]

13. Berridge, K.C.; Kringelbach, M.L. Affective neuroscience of pleasure: Reward in humans and animals. Psychopharmacology 2008, 199, 457-480. [CrossRef] [PubMed]

14. Berridge, K.C.; Robinson, T.E.; Aldridge, J.W. Dissecting components of reward: 'Liking', 'wanting', and learning. Curr. Opin. Pharmacol. 2009, 9, 65-73. [CrossRef] [PubMed]

15. Levine, A.S.; Billington, C.J. Opioids as agents of reward-related feeding: A consideration of the evidence. Physiol. Behav. 2004, 82, 57-61. [CrossRef] [PubMed]

16. Smith, K.S.; Berridge, K.C. Opioid limbic circuit for reward: Interaction between hedonic hotspots of nucleus accumbens and ventral pallidum. J. Neurosci. 2007, 27, 1594-1605. [CrossRef] [PubMed]

17. Berridge, K.C.; Ho, C.Y.; Richard, J.M.; DiFeliceantonio, A.G. The tempted brain eats: Pleasure and desire circuits in obesity and eating disorders. Brain Res. 2010, 1350, 43-64. [CrossRef] [PubMed]

18. Robinson, T.E.; Berridge, K.C. The incentive sensitization theory of addiction: Some current issues. Philos. Trans. R. Soc. Lond. B Biol. Sci. 2008, 363, 3137-3146. [CrossRef] [PubMed]

19. Berridge, K.C.; Robinson, T.E. Liking, wanting, and the incentive-sensitization theory of addiction. Am. Psychol. 2016, 71, 670-679. [CrossRef] [PubMed]

20. Robinson, T.E.; Berridge, K.C. Addiction. Annu. Rev. Psychol. 2003, 54, 25-53. [CrossRef] [PubMed]

21. Robinson, M.J.; Fischer, A.M.; Ahuja, A.; Lesser, E.N.; Maniates, H. Roles of "wanting" and "liking" in motivating behavior: Gambling, food, and drug addictions. Curr. Top. Behav. Neurosci. 2016, 27, 105-136. [PubMed]

22. Koob, G.F.; Volkow, N.D. Neurobiology of addiction: A neurocircuitry analysis. Lancet Psychiatry 2016, 3, 760-773. [CrossRef]

23. Koob, G.F.; Volkow, N.D. Neurocircuitry of addiction. Neuropsychopharmacology 2010, 35, 217-238. [CrossRef] [PubMed]

24. Steiner, J.E.; Glaser, D.; Hawilo, M.E.; Berridge, K.C. Comparative expression of hedonic impact: Affective reactions to taste by human infants and other primates. Neurosci. Biobehav. Rev. 2001, 25, 53-74. [CrossRef]

25. Steiner, J.E. The gustofacial response: Observation on normal and anencephalic newborn infants. Symp. Oral Sens. Percept. 1973, 4, 254-278.

26. Grill, H.J.; Norgren, R. The taste reactivity test. II. Mimetic responses to gustatory stimuli in chronic thalamic and chronic decerebrate rats. Brain Res. 1978, 143, 281-297. [CrossRef]

27. Olszewski, P.K.; Levine, A.S. Central opioids and consumption of sweet tastants: When reward outweighs homeostasis. Physiol. Behav. 2007, 91, 506-512. [CrossRef] [PubMed]

28. Nogueiras, R.; Romero-Pico, A.; Vazquez, M.J.; Novelle, M.G.; Lopez, M.; Dieguez, C. The opioid system and food intake: Homeostatic and hedonic mechanisms. Obes. Facts 2012, 5, 196-207. [CrossRef] [PubMed]

29. Bodnar, R.J. Endogenous opiates and behavior: 2012. Peptides 2013, 50, 55-95. [CrossRef] [PubMed]

30. Marks-Kaufman, R. Increased fat consumption induced by morphine administration in rats. Pharmacol. Biochem. Behav. 1982, 16, 949-955. [CrossRef]

31. Marks-Kaufman, R.; Kanarek, R.B. Modifications of nutrient selection induced by naloxone in rats. Psychopharmacology 1981, 74, 321-324. [CrossRef] [PubMed] 
32. Gosnell, B.A.; Krahn, D.D.; Majchrzak, M.J. The effects of morphine on diet selection are dependent upon baseline diet preferences. Pharmacol. Biochem. Behav. 1990, 37, 207-212. [CrossRef]

33. Glass, M.J.; Grace, M.; Cleary, J.P.; Billington, C.J.; Levine, A.S. Potency of naloxone's anorectic effect in rats is dependent on diet preference. Am. J. Physiol. 1996, 271, R217-R221. [CrossRef] [PubMed]

34. Glass, M.J.; Billington, C.J.; Levine, A.S. Naltrexone administered to central nucleus of amygdala or PVN: Neural dissociation of diet and energy. Am. J. Physiol. Regul. Integr. Comp. Physiol. 2000, 279, R86-R92. [CrossRef] [PubMed]

35. Smith, K.S.; Berridge, K.C.; Aldridge, J.W. Disentangling pleasure from incentive salience and learning signals in brain reward circuitry. Proc. Natl. Acad. Sci. USA 2011, 108, E255-E264. [CrossRef] [PubMed]

36. Pecina, S.; Berridge, K.C. Hedonic hot spot in nucleus accumbens shell: Where do mu-opioids cause increased hedonic impact of sweetness? J. Neurosci. 2005, 25, 11777-11786. [CrossRef] [PubMed]

37. Castro, D.C.; Berridge, K.C. Opioid hedonic hotspot in nucleus accumbens shell: Mu, delta, and kappa maps for enhancement of sweetness "liking" and "wanting". J. Neurosci. 2014, 34, 4239-4250. [CrossRef] [PubMed]

38. Giuliano, C.; Cottone, P. The role of the opioid system in binge eating disorder. CNS Spectr. 2015, 20, 537-545. [CrossRef] [PubMed]

39. Zhang, M.; Gosnell, B.A.; Kelley, A.E. Intake of high-fat food is selectively enhanced by mu opioid receptor stimulation within the nucleus accumbens. J. Pharmacol. Exp. Ther. 1998, 285, 908-914. [PubMed]

40. Woolley, J.D.; Lee, B.S.; Fields, H.L. Nucleus accumbens opioids regulate flavor-based preferences in food consumption. Neuroscience 2006, 143, 309-317. [CrossRef] [PubMed]

41. Bakshi, V.P.; Kelley, A.E. Feeding induced by opioid stimulation of the ventral striatum: Role of opiate receptor subtypes. J. Pharmacol. Exp. Ther. 1993, 265, 1253-1260. [PubMed]

42. Mena, J.D.; Sadeghian, K.; Baldo, B.A. Induction of hyperphagia and carbohydrate intake by mu-opioid receptor stimulation in circumscribed regions of frontal cortex. J. Neurosci. 2011, 31, 3249-3260. [CrossRef] [PubMed]

43. Ng, L.; Davis, C. Cravings and food consumption in binge eating disorder. Eat. Behav. 2013, 14, 472-475. [CrossRef] [PubMed]

44. Drewnowski, A.; Krahn, D.D.; Demitrack, M.A.; Nairn, K.; Gosnell, B.A. Naloxone, an opiate blocker, reduces the consumption of sweet high-fat foods in obese and lean female binge eaters. Am. J. Clin. Nutr. 1995, 61, 1206-1212. [CrossRef] [PubMed]

45. Drewnowski, A.; Krahn, D.D.; Demitrack, M.A.; Nairn, K.; Gosnell, B.A. Taste responses and preferences for sweet high-fat foods: Evidence for opioid involvement. Physiol. Behav. 1992, 51, 371-379. [CrossRef]

46. Yeomans, M.R.; Gray, R.W. Selective effects of naltrexone on food pleasantness and intake. Physiol. Behav. 1996, 60, 439-446. [CrossRef]

47. Pecina, S.; Berridge, K.C. Dopamine or opioid stimulation of nucleus accumbens similarly amplify cue-triggered 'wanting' for reward: Entire core and medial shell mapped as substrates for pit enhancement. Eur. J. Neurosci. 2013, 37, 1529-1540. [CrossRef] [PubMed]

48. Cottone, P.; Sabino, V.; Steardo, L.; Zorrilla, E.P. Opioid-dependent anticipatory negative contrast and binge-like eating in rats with limited access to highly preferred food. Neuropsychopharmacology 2008, 33, 524-535. [CrossRef] [PubMed]

49. Cartoni, E.; Puglisi-Allegra, S.; Baldassarre, G. The three principles of action: A pavlovian-instrumental transfer hypothesis. Front. Behav. Neurosci. 2013, 7. [CrossRef] [PubMed]

50. Giuliano, C.; Robbins, T.W.; Nathan, P.J.; Bullmore, E.T.; Everitt, B.J. Inhibition of opioid transmission at the mu-opioid receptor prevents both food seeking and binge-like eating. Neuropsychopharmacology 2012, 37, 2643-2652. [CrossRef] [PubMed]

51. Cambridge, V.C.; Ziauddeen, H.; Nathan, P.J.; Subramaniam, N.; Dodds, C.; Chamberlain, S.R.; Koch, A.; Maltby, K.; Skeggs, A.L.; Napolitano, A.; et al. Neural and behavioral effects of a novel mu opioid receptor antagonist in binge-eating obese people. Biol. Psychiatry 2013, 73, 887-894. [CrossRef] [PubMed]

52. Fields, H.L.; Margolis, E.B. Understanding opioid reward. Trends Neurosci. 2015, 38, 217-225. [CrossRef] [PubMed]

53. Mahler, S.V.; Berridge, K.C. What and when to "want"? Amygdala-based focusing of incentive salience upon sugar and sex. Psychopharmacology 2012, 221, 407-426. [CrossRef] [PubMed] 
54. DiFeliceantonio, A.G.; Berridge, K.C. Which cue to 'want'? Opioid stimulation of central amygdala makes goal-trackers show stronger goal-tracking, just as sign-trackers show stronger sign-tracking. Behav. Brain Res. 2012, 230, 399-408. [CrossRef] [PubMed]

55. Blasio, A.; Steardo, L.; Sabino, V.; Cottone, P. Opioid system in the medial prefrontal cortex mediates binge-like eating. Addict. Biol. 2014, 19, 652-662. [CrossRef] [PubMed]

56. Selleck, R.A.; Lake, C.; Estrada, V.; Riederer, J.; Andrzejewski, M.; Sadeghian, K.; Baldo, B.A. Endogenous opioid signaling in the medial prefrontal cortex is required for the expression of hunger-induced impulsive action. Neuropsychopharmacology 2015, 40, 2464-2474. [CrossRef] [PubMed]

57. Baldo, B.A. Prefrontal cortical opioids and dysregulated motivation: A network hypothesis. Trends Neurosci. 2016, 39, 366-377. [CrossRef] [PubMed]

58. Selleck, R.A.; Baldo, B.A. Feeding-modulatory effects of mu-opioids in the medial prefrontal cortex: A review of recent findings and comparison to opioid actions in the nucleus accumbens. Psychopharmacology 2017, 234, 1439-1449. [CrossRef] [PubMed]

59. Ferenczi, E.A.; Zalocusky, K.A.; Liston, C.; Grosenick, L.; Warden, M.R.; Amatya, D.; Katovich, K.; Mehta, H.; Patenaude, B.; Ramakrishnan, C.; et al. Prefrontal cortical regulation of brainwide circuit dynamics and reward-related behavior. Science 2016, 351. [CrossRef] [PubMed]

60. Laurent, V.; Bertran-Gonzalez, J.; Chieng, B.C.; Balleine, B.W. Delta-opioid and dopaminergic processes in accumbens shell modulate the cholinergic control of predictive learning and choice. J. Neurosci. 2014, 34, 1358-1369. [CrossRef] [PubMed]

61. Laurent, V.; Wong, F.L.; Balleine, B.W. Delta-opioid receptors in the accumbens shell mediate the influence of both excitatory and inhibitory predictions on choice. Br. J. Pharmacol. 2015, 172, 562-570. [CrossRef] [PubMed]

62. Previc, F.H. Dopamine and the origins of human intelligence. Brain Cogn. 1999, 41, 299-350. [CrossRef] [PubMed]

63. Defronzo, R.A. Bromocriptine: A sympatholytic, D2-dopamine agonist for the treatment of type 2 diabetes. Diabetes Care 2011, 34, 789-794. [CrossRef] [PubMed]

64. Rebello, C.J.; Greenway, F.L. Reward-induced eating: Therapeutic approaches to addressing food cravings. Adv. Ther. 2016, 33, 1853-1866. [CrossRef] [PubMed]

65. Nogueiras, R.; Seeley, R.J. Our evolving understanding of the interaction between leptin and dopamine system to regulate ingestive behaviors. Mol. Metab. 2012, 1, 8-9. [CrossRef] [PubMed]

66. Kern, A.; Grande, C.; Smith, R.G. Apo-ghrelin receptor (apo-GHSR1A) regulates dopamine signaling in the brain. Front. Endocrinol. 2014, 5. [CrossRef] [PubMed]

67. Berridge, K.C. From prediction error to incentive salience: Mesolimbic computation of reward motivation. Eur. J. Neurosci. 2012, 35, 1124-1143. [CrossRef] [PubMed]

68. Berridge, K.C. The debate over dopamine's role in reward: The case for incentive salience. Psychopharmacology 2007, 191, 391-431. [CrossRef] [PubMed]

69. Wise, R.A. Dopamine, learning and motivation. Nat. Rev. Neurosci. 2004, 5, 483-494. [CrossRef] [PubMed]

70. Wise, R.A. Role of brain dopamine in food reward and reinforcement. Philos. Trans. R. Soc. Lond. B Biol. Sci. 2006, 361, 1149-1158. [CrossRef] [PubMed]

71. Zheng, H.; Berthoud, H.R. Neural systems controlling the drive to eat: Mind versus metabolism. Physiology 2008, 23, 75-83. [CrossRef] [PubMed]

72. Wise, R.A.; Spindler, J.; de Wit, H.; Gerberg, G.J. Neuroleptic-induced "anhedonia" in rats: Pimozide blocks reward quality of food. Science 1978, 201, 262-264. [CrossRef] [PubMed]

73. Wise, R.A. Dopamine and reward: The anhedonia hypothesis 30 years on. Neurotox. Res. 2008, 14, 169-183. [CrossRef] [PubMed]

74. Palmiter, R.D. Is dopamine a physiologically relevant mediator of feeding behavior? Trends Neurosci. 2007, 30, 375-381. [CrossRef] [PubMed]

75. Zhou, Q.Y.; Palmiter, R.D. Dopamine-deficient mice are severely hypoactive, adipsic, and aphagic. Cell 1995, 83, 1197-1209. [CrossRef]

76. Kelley, A.E.; Baldo, B.A.; Pratt, W.E.; Will, M.J. Corticostriatal-hypothalamic circuitry and food motivation: Integration of energy, action and reward. Physiol. Behav. 2005, 86, 773-795. [CrossRef] [PubMed]

77. Cameron, J.D.; Chaput, J.P.; Sjodin, A.M.; Goldfield, G.S. Brain on fire: Incentive salience, hedonic hot spots, dopamine, obesity, and other hunger games. Annu. Rev. Nutr. 2017, 37, 183-205. [CrossRef] [PubMed] 
78. Di Chiara, G.; Morelli, M.; Consolo, S. Modulatory functions of neurotransmitters in the striatum: Ach/dopamine/nmda interactions. Trends Neurosci. 1994, 17, 228-233. [CrossRef]

79. Baldo, B.A.; Sadeghian, K.; Basso, A.M.; Kelley, A.E. Effects of selective dopamine D1 or D2 receptor blockade within nucleus accumbens subregions on ingestive behavior and associated motor activity. Behav. Brain Res. 2002, 137, 165-177. [CrossRef]

80. Cousins, M.S.; Atherton, A.; Turner, L.; Salamone, J.D. Nucleus accumbens dopamine depletions alter relative response allocation in a T-maze cost/benefit task. Behav. Brain Res. 1996, 74, 189-197. [CrossRef]

81. Salamone, J.D.; Arizzi, M.N.; Sandoval, M.D.; Cervone, K.M.; Aberman, J.E. Dopamine antagonists alter response allocation but do not suppress appetite for food in rats: Contrast between the effects of SKF 83566, raclopride, and fenfluramine on a concurrent choice task. Psychopharmacology 2002, 160, 371-380. [CrossRef] [PubMed]

82. Salamone, J.D.; Cousins, M.S.; Bucher, S. Anhedonia or anergia? Effects of haloperidol and nucleus accumbens dopamine depletion on instrumental response selection in a T-maze cost/benefit procedure. Behav. Brain Res. 1994, 65, 221-229. [CrossRef]

83. Cannon, C.M.; Palmiter, R.D. Reward without dopamine. J. Neurosci. 2003, 23, 10827-10831. [PubMed]

84. Wise, R.A. Brain reward circuitry: Insights from unsensed incentives. Neuron 2002, 36, 229-240. [CrossRef]

85. Palmiter, R.D. Dopamine signaling in the dorsal striatum is essential for motivated behaviors: Lessons from dopamine-deficient mice. Ann. N. Y. Acad. Sci. 2008, 1129, 35-46. [CrossRef] [PubMed]

86. Stelzel, C.; Basten, U.; Montag, C.; Reuter, M.; Fiebach, C.J. Frontostriatal involvement in task switching depends on genetic differences in D2 receptor density. J. Neurosci. 2010, 30, 14205-14212. [CrossRef] [PubMed]

87. Trifilieff, P.; Feng, B.; Urizar, E.; Winiger, V.; Ward, R.D.; Taylor, K.M.; Martinez, D.; Moore, H.; Balsam, P.D.; Simpson, E.H.; et al. Increasing dopamine D2 receptor expression in the adult nucleus accumbens enhances motivation. Mol. Psychiatry 2013, 18, 1025-1033. [CrossRef] [PubMed]

88. Blum, K.; Braverman, E.R.; Holder, J.M.; Lubar, J.F.; Monastra, V.J.; Miller, D.; Lubar, J.O.; Chen, T.J.; Comings, D.E. Reward deficiency syndrome: A biogenetic model for the diagnosis and treatment of impulsive, addictive, and compulsive behaviors. J. Psychoact. Drugs 2000, 32, 1-112. [CrossRef]

89. Johnson, P.M.; Kenny, P.J. Dopamine D2 receptors in addiction-like reward dysfunction and compulsive eating in obese rats. Nat. Neurosci. 2010, 13, 635-641. [CrossRef] [PubMed]

90. Stice, E.; Yokum, S.; Blum, K.; Bohon, C. Weight gain is associated with reduced striatal response to palatable food. J. Neurosci. 2010, 30, 13105-13109. [CrossRef] [PubMed]

91. Stice, E.; Yokum, S. Gain in body fat is associated with increased striatal response to palatable food cues, whereas body fat stability is associated with decreased striatal response. J. Neurosci. 2016, 36, 6949-6956. [CrossRef] [PubMed]

92. Rogers, P.J. Food and drug addictions: Similarities and differences. Pharmacol. Biochem. Behav. 2017, 153, 182-190. [CrossRef] [PubMed]

93. Colantuoni, C.; Schwenker, J.; McCarthy, J.; Rada, P.; Ladenheim, B.; Cadet, J.L.; Schwartz, G.J.; Moran, T.H.; Hoebel, B.G. Excessive sugar intake alters binding to dopamine and mu-opioid receptors in the brain. Neuroreport 2001, 12, 3549-3552. [CrossRef] [PubMed]

94. Volkow, N.D.; Wang, G.J.; Telang, F.; Fowler, J.S.; Thanos, P.K.; Logan, J.; Alexoff, D.; Ding, Y.S.; Wong, C.; Ma, Y.; et al. Low dopamine striatal D2 receptors are associated with prefrontal metabolism in obese subjects: Possible contributing factors. Neuroimage 2008, 42, 1537-1543. [CrossRef] [PubMed]

95. De Weijer, B.A.; van de Giessen, E.; van Amelsvoort, T.A.; Boot, E.; Braak, B.; Janssen, I.M.; van de Laar, A.; Fliers, E.; Serlie, M.J.; Booij, J. Lower striatal dopamine D2/3 receptor availability in obese compared with non-obese subjects. EJNMMI Res. 2011, 1. [CrossRef] [PubMed]

96. Wilcox, C.E.; Braskie, M.N.; Kluth, J.T.; Jagust, W.J. Overeating behavior and striatal dopamine with 6-[F]-Fluoro-L-m-tyrosine pet. J. Obes. 2010, 2010. [CrossRef] [PubMed]

97. Babbs, R.K.; Sun, X.; Felsted, J.; Chouinard-Decorte, F.; Veldhuizen, M.G.; Small, D.M. Decreased caudate response to milkshake is associated with higher body mass index and greater impulsivity. Physiol. Behav. 2013, 121, 103-111. [CrossRef] [PubMed]

98. Bello, N.T.; Hajnal, A. Dopamine and binge eating behaviors. Pharmacol. Biochem. Behav. 2010, 97, $25-33$. [CrossRef] [PubMed] 
99. Dunn, J.P.; Kessler, R.M.; Feurer, I.D.; Volkow, N.D.; Patterson, B.W.; Ansari, M.S.; Li, R.; Marks-Shulman, P.; Abumrad, N.N. Relationship of dopamine type 2 receptor binding potential with fasting neuroendocrine hormones and insulin sensitivity in human obesity. Diabetes Care 2012, 35, 1105-1111. [CrossRef] [PubMed]

100. Stice, E.; Spoor, S.; Bohon, C.; Small, D.M. Relation between obesity and blunted striatal response to food is moderated by Taqia A1 allele. Science 2008, 322, 449-452. [CrossRef] [PubMed]

101. Halpern, C.H.; Tekriwal, A.; Santollo, J.; Keating, J.G.; Wolf, J.A.; Daniels, D.; Bale, T.L. Amelioration of binge eating by nucleus accumbens shell deep brain stimulation in mice involves D2 receptor modulation. J. Neurosci. 2013, 33, 7122-7129. [CrossRef] [PubMed]

102. Doucette, W.T.; Khokhar, J.Y.; Green, A.I. Nucleus accumbens deep brain stimulation in a rat model of binge eating. Transl. Psychiatry 2015, 5, e695. [CrossRef] [PubMed]

103. Xu, P.; He, Y.; Cao, X.; Valencia-Torres, L.; Yan, X.; Saito, K.; Wang, C.; Yang, Y.; Hinton, A., Jr.; Zhu, L.; et al. Activation of serotonin $2 \mathrm{C}$ receptors in dopamine neurons inhibits binge-like eating in mice. Biol. Psychiatry 2017, 81, 737-747. [CrossRef] [PubMed]

104. Berridge, K.C. Espresso reward learning, hold the dopamine: Theoretical comment on Robinson et al. (2005). Behav. Neurosci. 2005, 119, 336-341. [CrossRef] [PubMed]

105. Kravitz, A.V.; Tye, L.D.; Kreitzer, A.C. Distinct roles for direct and indirect pathway striatal neurons in reinforcement. Nat. Neurosci. 2012, 15, 816-818. [CrossRef] [PubMed]

106. Petrovich, G.D. Learning and the motivation to eat: Forebrain circuitry. Physiol. Behav. 2011, 104, 582-589. [CrossRef] [PubMed]

107. Reppucci, C.J.; Petrovich, G.D. Learned food-cue stimulates persistent feeding in sated rats. Appetite 2012, 59, 437-447. [CrossRef] [PubMed]

108. Reichelt, A.C.; Westbrook, R.F.; Morris, M.J. Integration of reward signalling and appetite regulating peptide systems in the control of food-cue responses. Br. J. Pharmacol. 2015, 172, 5225-5238. [CrossRef] [PubMed]

109. Galarce, E.M.; Crombag, H.S.; Holland, P.C. Reinforcer-specificity of appetitive and consummatory behavior of rats after pavlovian conditioning with food reinforcers. Physiol. Behav. 2007, 91, 95-105. [CrossRef] [PubMed]

110. Flagel, S.B.; Clark, J.J.; Robinson, T.E.; Mayo, L.; Czuj, A.; Willuhn, I.; Akers, C.A.; Clinton, S.M.; Phillips, P.E.; Akil, H. A selective role for dopamine in stimulus-reward learning. Nature 2011, 469, 53-57. [CrossRef] [PubMed]

111. Land, B.B.; Narayanan, N.S.; Liu, R.J.; Gianessi, C.A.; Brayton, C.E.; Grimaldi, D.M.; Sarhan, M.; Guarnieri, D.J.; Deisseroth, K.; Aghajanian, G.K.; et al. Medial prefrontal D1 dopamine neurons control food intake. Nat. Neurosci. 2014, 17, 248-253. [CrossRef] [PubMed]

112. Everitt, B.J.; Robbins, T.W. Neural systems of reinforcement for drug addiction: From actions to habits to compulsion. Nat. Neurosci. 2005, 8, 1481-1489. [CrossRef] [PubMed]

113. Yoest, K.E.; Cummings, J.A.; Becker, J.B. Estradiol, dopamine and motivation. Cent. Nerv. Syst. Agents Med. Chem. 2014, 14, 83-89. [CrossRef] [PubMed]

114. Puglisi-Allegra, S.; Ventura, R. Prefrontal/accumbal catecholamine system processes emotionally driven attribution of motivational salience. Rev. Neurosci. 2012, 23, 509-526. [CrossRef] [PubMed]

115. Leng, G.; Sabatier, N. Oxytocin-The sweet hormone? Trends Endocrinol. Metab. 2017, 28, 365-376. [CrossRef] [PubMed]

116. Figlewicz, D.P.; MacDonald Naleid, A.; Sipols, A.J. Modulation of food reward by adiposity signals. Physiol. Behav. 2007, 91, 473-478. [CrossRef] [PubMed]

117. Opland, D.M.; Leinninger, G.M.; Myers, M.G., Jr. Modulation of the mesolimbic dopamine system by leptin. Brain Res. 2010, 1350, 65-70. [CrossRef] [PubMed]

118. Perello, M.; Dickson, S.L. Ghrelin signalling on food reward: A salient link between the gut and the mesolimbic system. J. Neuroendocrinol. 2015, 27, 424-434. [CrossRef] [PubMed]

119. Van Zessen, R.; van der Plasse, G.; Adan, R.A. Contribution of the mesolimbic dopamine system in mediating the effects of leptin and ghrelin on feeding. Proc. Nutr. Soc. 2012, 71, 435-445. [CrossRef] [PubMed]

120. Murray, S.; Tulloch, A.; Gold, M.S.; Avena, N.M. Hormonal and neural mechanisms of food reward, eating behaviour and obesity. Nat. Rev. Endocrinol. 2014, 10, 540-552. [CrossRef] [PubMed]

121. D’Addario, C.; Micioni Di Bonaventura, M.V.; Pucci, M.; Romano, A.; Gaetani, S.; Ciccocioppo, R.; Cifani, C.; Maccarrone, M. Endocannabinoid signaling and food addiction. Neurosci. Biobehav. Rev. 2014, 47, $203-224$. [CrossRef] [PubMed] 
122. Parsons, L.H.; Hurd, Y.L. Endocannabinoid signalling in reward and addiction. Nat. Rev. Neurosci. 2015, 16, 579-594. [CrossRef] [PubMed]

123. Edwards, A.; Abizaid, A. Driving the need to feed: Insight into the collaborative interaction between ghrelin and endocannabinoid systems in modulating brain reward systems. Neurosci. Biobehav. Rev. 2016, 66, 33-53. [CrossRef] [PubMed]

124. Randolph, T.G. The descriptive features of food addiction; addictive eating and drinking. Q. J. Stud. Alcohol. 1956, 17, 198-224. [PubMed]

125. National Institute on Drug Abuse (NIDA). “Media Guide”. National Institute on Drug Abuse; 1 October 2016. Available online: https:/ / www.drugabuse.gov/publications/media-guide (accessed on 11 October 2017).

126. Herman, M.A.; Roberto, M. The addicted brain: Understanding the neurophysiological mechanisms of addictive disorders. Front. Integr. Neurosci. 2015, 9. [CrossRef] [PubMed]

127. Moore, C.F.; Sabino, V.; Koob, G.F.; Cottone, P. Neuroscience of compulsive eating behavior. Front. Neurosci. 2017, 11. [CrossRef] [PubMed]

128. Feltenstein, M.W.; See, R.E. The neurocircuitry of addiction: An overview. Br. J. Pharmacol. 2008, 154, $261-274$. [CrossRef] [PubMed]

129. Hone-Blanchet, A.; Fecteau, S. Overlap of food addiction and substance use disorders definitions: Analysis of animal and human studies. Neuropharmacology 2014, 85, 81-90. [CrossRef] [PubMed]

130. Hutson, P.H.; Balodis, I.M.; Potenza, M.N. Binge-eating disorder: Clinical and therapeutic advances. Pharmacol. Ther. 2017. [CrossRef] [PubMed]

131. Ng, M.; Fleming, T.; Robinson, M.; Thomson, B.; Graetz, N.; Margono, C.; Mullany, E.C.; Biryukov, S.; Abbafati, C.; Abera, S.F.; et al. Global, regional, and national prevalence of overweight and obesity in children and adults during 1980-2013: A systematic analysis for the global burden of disease study 2013. Lancet 2014, 384, 766-781. [CrossRef]

132. American Psychiatric Association. DSM-5: Diagnostic and Statistical Manual of Mental Disorders, 5th ed.; American Psychiatric Publishing: Washington, DC, USA, 2013; p. 947.

133. Schulte, E.M.; Joyner, M.A.; Potenza, M.N.; Grilo, C.M.; Gearhardt, A.N. Current considerations regarding food addiction. Curr. Psychiatry Rep. 2015, 17, 563. [CrossRef] [PubMed]

134. Ziauddeen, H.; Fletcher, P.C. Is food addiction a valid and useful concept? Obes. Rev. 2013, 14, 19-28. [CrossRef] [PubMed]

135. Finlayson, G. Food addiction and obesity: Unnecessary medicalization of hedonic overeating. Nat. Rev. Endocrinol. 2017, 13, 493-498. [CrossRef] [PubMed]

136. Hebebrand, J.; Albayrak, O.; Adan, R.; Antel, J.; Dieguez, C.; de Jong, J.; Leng, G.; Menzies, J.; Mercer, J.G.; Murphy, M.; et al. "Eating addiction", rather than "food addiction", better captures addictive-like eating behavior. Neurosci. Biobehav. Rev. 2014, 47, 295-306. [CrossRef] [PubMed]

137. Carter, A.; Hendrikse, J.; Lee, N.; Yucel, M.; Verdejo-Garcia, A.; Andrews, Z.; Hall, W. The neurobiology of "food addiction" and its implications for obesity treatment and policy. Annu. Rev. Nutr. 2016, 36, 105-128. [CrossRef] [PubMed]

138. Vella, S.L.; Pai, N. What is in a name? Is food addiction a misnomer? Asian J. Psychiatry 2017, 25, $123-126$. [CrossRef] [PubMed]

139. Blumenthal, D.M.; Gold, M.S. Neurobiology of food addiction. Curr. Opin. Clin. Nutr. Metab. Care 2010, 13, 359-365. [CrossRef] [PubMed]

140. Corwin, R.L.; Grigson, P.S. Symposium overview—Food addiction: Fact or fiction? J. Nutr. 2009, 139, 617-619. [CrossRef] [PubMed]

141. Pelchat, M.L. Food addiction in humans. J. Nutr. 2009, 139, 620-622. [CrossRef] [PubMed]

142. Davis, C. A commentary on the associations among 'food addiction', binge eating disorder, and obesity: Overlapping conditions with idiosyncratic clinical features. Appetite 2017, 115, 3-8. [CrossRef] [PubMed]

143. Ifland, J.R.; Preuss, H.G.; Marcus, M.T.; Rourke, K.M.; Taylor, W.C.; Burau, K.; Jacobs, W.S.; Kadish, W.; Manso, G. Refined food addiction: A classic substance use disorder. Med. Hypotheses 2009, 72, 518-526. [CrossRef] [PubMed]

144. Corsica, J.A.; Pelchat, M.L. Food addiction: True or false? Curr. Opin. Gastroenterol. 2010, 26, 165-169. [CrossRef] [PubMed] 
145. Albayrak, O.; Wolfle, S.M.; Hebebrand, J. Does food addiction exist? A phenomenological discussion based on the psychiatric classification of substance-related disorders and addiction. Obes. Facts 2012, 5, 165-179. [CrossRef] [PubMed]

146. Deroche-Gamonet, V.; Belin, D.; Piazza, P.V. Evidence for addiction-like behavior in the rat. Science 2004, 305, 1014-1017. [CrossRef] [PubMed]

147. La Fleur, S.E.; Luijendijk, M.C.; van Rozen, A.J.; Kalsbeek, A.; Adan, R.A. A free-choice high-fat high-sugar diet induces glucose intolerance and insulin unresponsiveness to a glucose load not explained by obesity. Int. J. Obes. 2011, 35, 595-604. [CrossRef] [PubMed]

148. Lieblich, I.; Cohen, E.; Ganchrow, J.R.; Blass, E.M.; Bergmann, F. Morphine tolerance in genetically selected rats induced by chronically elevated saccharin intake. Science 1983, 221, 871-873. [CrossRef] [PubMed]

149. Woods, S.C. The eating paradox: How we tolerate food. Psychol. Rev. 1991, 98, 488-505. [CrossRef] [PubMed]

150. Ghitza, U.E.; Gray, S.M.; Epstein, D.H.; Rice, K.C.; Shaham, Y. The anxiogenic drug yohimbine reinstates palatable food seeking in a rat relapse model: A role of CRF1 receptors. Neuropsychopharmacology 2006, 31, 2188-2196. [CrossRef] [PubMed]

151. Latagliata, E.C.; Patrono, E.; Puglisi-Allegra, S.; Ventura, R. Food seeking in spite of harmful consequences is under prefrontal cortical noradrenergic control. BMC Neurosci. 2010, 11. [CrossRef] [PubMed]

152. Granero, R.; Hilker, I.; Aguera, Z.; Jimenez-Murcia, S.; Sauchelli, S.; Islam, M.A.; Fagundo, A.B.; Sanchez, I.; Riesco, N.; Dieguez, C.; et al. Food addiction in a Spanish sample of eating disorders: DSM-5 diagnostic subtype differentiation and validation data. Eur. Eat. Disord. Rev. 2014, 22, 389-396. [CrossRef] [PubMed]

153. De Jong, J.W.; Vanderschuren, L.J.; Adan, R.A. Towards an animal model of food addiction. Obes. Facts 2012, 5, 180-195. [CrossRef] [PubMed]

154. Regier, D.A.; Kuhl, E.A.; Kupfer, D.J. The DSM-5: Classification and criteria changes. World Psychiatry 2013, 12, 92-98. [CrossRef] [PubMed]

155. Gearhardt, A.N.; White, M.A.; Potenza, M.N. Binge eating disorder and food addiction. Curr. Drug Abuse Rev. 2011, 4, 201-207. [CrossRef] [PubMed]

156. Burrows, T.; Skinner, J.; McKenna, R.; Rollo, M. Food addiction, binge eating disorder, and obesity: Is there a relationship? Behav. Sci. 2017, 7. [CrossRef] [PubMed]

157. Avena, N.M.; Long, K.A.; Hoebel, B.G. Sugar-dependent rats show enhanced responding for sugar after abstinence: Evidence of a sugar deprivation effect. Physiol. Behav. 2005, 84, 359-362. [CrossRef] [PubMed]

158. Avena, N.M.; Rada, P.; Hoebel, B.G. Evidence for sugar addiction: Behavioral and neurochemical effects of intermittent, excessive sugar intake. Neurosci. Biobehav. Rev. 2008, 32, 20-39. [CrossRef] [PubMed]

159. Gold, M.S.; Graham, N.A.; Cocores, J.A.; Nixon, S.J. Food addiction? J. Addict. Med. 2009, 3, 42-45. [CrossRef] [PubMed]

160. Parylak, S.L.; Koob, G.F.; Zorrilla, E.P. The dark side of food addiction. Physiol. Behav. 2011, 104, $149-156$. [CrossRef] [PubMed]

161. Perello, M.; Valdivia, S.; Garcia Romero, G.; Raingo, J. Considerations about rodent models of binge eating episodes. Front. Psychol. 2014, 5. [CrossRef] [PubMed]

162. Avena, N.M. The study of food addiction using animal models of binge eating. Appetite 2010, 55, 734-737. [CrossRef] [PubMed]

163. Avena, N.M.; Rada, P.; Hoebel, B.G. Sugar and fat bingeing have notable differences in addictive-like behavior. J. Nutr. 2009, 139, 623-628. [CrossRef] [PubMed]

164. Avena, N.M. Animal models of eating disorders. In Neuromethods; Springer: New York, NY, USA, 2013 ; p. 379.

165. Casper, R.C.; Sullivan, E.L.; Tecott, L. Relevance of animal models to human eating disorders and obesity. Psychopharmacology 2008, 199, 313-329. [CrossRef] [PubMed]

166. Corwin, R.L.; Babbs, R.K. Rodent models of binge eating: Are they models of addiction? ILAR J. 2012, 53, 23-34. [CrossRef] [PubMed]

167. Di Segni, M.; Patrono, E.; Patella, L.; Puglisi-Allegra, S.; Ventura, R. Animal models of compulsive eating behavior. Nutrients 2014, 6, 4591-4609. [CrossRef] [PubMed]

168. Kim, S.F. Animal models of eating disorders. Neuroscience 2012, 211, 2-12. [CrossRef] [PubMed]

169. Razzoli, M.; Pearson, C.; Crow, S.; Bartolomucci, A. Stress, overeating, and obesity: Insights from human studies and preclinical models. Neurosci. Biobehav. Rev. 2017, 76, 154-162. [CrossRef] [PubMed]

170. Turton, R.; Chami, R.; Treasure, J. Emotional eating, binge eating and animal models of binge-type eating disorders. Curr. Obes. Rep. 2017, 6, 217-228. [CrossRef] [PubMed] 
171. Trace, S.E.; Baker, J.H.; Penas-Lledo, E.; Bulik, C.M. The genetics of eating disorders. Annu. Rev. Clin. Psychol. 2013, 9, 589-620. [CrossRef] [PubMed]

172. Yilmaz, Z.; Hardaway, J.A.; Bulik, C.M. Genetics and epigenetics of eating disorders. Adv. Genom. Genet. 2015, 5, 131-150.

173. Thaler, L.; Steiger, H. Eating disorders and epigenetics. Adv. Exp. Med. Biol. 2017, 978, 93-103. [PubMed]

174. Davis, C. The epidemiology and genetics of binge eating disorder (BED). CNS Spectr. 2015, 20, 522-529. [CrossRef] [PubMed]

175. Meyre, D.; Mayhew, A.; Pigeyre, M.; Couturier, J. An evolutionary genetic perspective of eating disorders. Neuroendocrinology 2017. [CrossRef] [PubMed]

176. Patrono, E.; Di Segni, M.; Patella, L.; Andolina, D.; Valzania, A.; Latagliata, E.C.; Felsani, A.; Pompili, A.; Gasbarri, A.; Puglisi-Allegra, S.; et al. When chocolate seeking becomes compulsion: Gene-environment interplay. PLoS ONE 2015, 10, e0120191. [CrossRef] [PubMed]

177. Kirkpatrick, S.L.; Goldberg, L.R.; Yazdani, N.; Babbs, R.K.; Wu, J.; Reed, E.R.; Jenkins, D.F.; Bolgioni, A.F.; Landaverde, K.I.; Luttik, K.P.; et al. Cytoplasmic FMR1-interacting protein 2 is a major genetic factor underlying binge eating. Biol. Psychiatry 2017, 81, 757-769. [CrossRef] [PubMed]

178. Goldberg, L.R.; Kirkpatrick, S.L.; Yazdani, N.; Luttik, K.P.; Lacki, O.A.; Keith Babbs, R.; Jenkins, D.F.; Evan Johnson, W.; Bryant, C.D. Casein kinase 1-epsilon deletion increases mu opioid receptor-dependent behaviors and binge eating. Genes Brain Behav. 2017, 16, 725-738. [CrossRef] [PubMed]

179. Babbs, R.K.; Kelliher, J.C.; Scotellaro, J.L.; Yazdani, N.; Ruan, Q.T.; Mulligan, M.K.; Bryant, C.D. Genetic differences in the behavioral organization of binge eating, conditioned food reward, and compulsive-like eating in C57BL/6J and DBA/2J strains. bioRxiv 2017. [CrossRef]

180. Hildebrandt, B.A.; Klump, K.L.; Racine, S.E.; Sisk, C.L. Differential strain vulnerability to binge eating behaviors in rats. Physiol. Behav. 2014, 127, 81-86. [CrossRef] [PubMed]

181. Yu, Z.; Geary, N.; Corwin, R.L. Ovarian hormones inhibit fat intake under binge-type conditions in ovariectomized rats. Physiol. Behav. 2008, 95, 501-507. [CrossRef] [PubMed]

182. Yu, Z.; Geary, N.; Corwin, R.L. Individual effects of estradiol and progesterone on food intake and body weight in ovariectomized binge rats. Physiol. Behav. 2011, 104, 687-693. [CrossRef] [PubMed]

183. Babbs, R.K.; Wojnicki, F.H.; Corwin, R.L. Effect of 2-hydroxyestradiol on binge intake in rats. Physiol. Behav. 2011, 103, 508-512. [CrossRef] [PubMed]

184. Babbs, R.K.; Unger, E.L.; Corwin, R.L. 2-hydroxyestradiol enhances binge onset in female rats and reduces prefrontal cortical dopamine in male rats. Horm. Behav. 2013, 63, 88-96. [CrossRef] [PubMed]

185. Bekker, L.; Barnea, R.; Brauner, A.; Weller, A. Adolescent rats are more prone to binge eating behavior: A study of age and obesity as risk factors. Behav. Brain Res. 2014, 270, 108-111. [CrossRef] [PubMed]

186. Czyzyk, T.A.; Sahr, A.E.; Statnick, M.A. A model of binge-like eating behavior in mice that does not require food deprivation or stress. Obesity 2010, 18, 1710-1717. [CrossRef] [PubMed]

187. Boggiano, M.M.; Artiga, A.I.; Pritchett, C.E.; Chandler-Laney, P.C.; Smith, M.L.; Eldridge, A.J. High intake of palatable food predicts binge-eating independent of susceptibility to obesity: An animal model of lean vs. obese binge-eating and obesity with and without binge-eating. Int. J. Obes. 2007, 31, 1357-1367. [CrossRef] [PubMed]

188. Freund, N.; Thompson, B.S.; Norman, K.J.; Einhorn, P.; Andersen, S.L. Developmental emergence of an obsessive-compulsive phenotype and binge behavior in rats. Psychopharmacology 2015, 232, 3173-3181. [CrossRef] [PubMed]

189. Peterson, C.B.; Thuras, P.; Ackard, D.M.; Mitchell, J.E.; Berg, K.; Sandager, N.; Wonderlich, S.A.; Pederson, M.W.; Crow, S.J. Personality dimensions in bulimia nervosa, binge eating disorder, and obesity. Compr. Psychiatry 2010, 51, 31-36. [CrossRef] [PubMed]

190. Chawla, A.; Cordner, Z.A.; Boersma, G.; Moran, T.H. Cognitive impairment and gene expression alterations in a rodent model of binge eating disorder. Physiol. Behav. 2017, 180, 78-90. [CrossRef] [PubMed]

191. Lutter, M.; Bahl, E.; Hannah, C.; Hofammann, D.; Acevedo, S.; Cui, H.; McAdams, C.J.; Michaelson, J.J. Novel and ultra-rare damaging variants in neuropeptide signaling are associated with disordered eating behaviors. PLoS ONE 2017, 12, e0181556. [CrossRef] [PubMed] 
192. Pucci, M.; Micioni Di Bonaventura, M.V.; Giusepponi, M.E.; Romano, A.; Filaferro, M.; Maccarrone, M.; Ciccocioppo, R.; Cifani, C.; D'Addario, C. Epigenetic regulation of nociceptin/orphanin FQ and corticotropin-releasing factor system genes in frustration stress-induced binge-like palatable food consumption. Addict. Biol. 2016, 21, 1168-1185. [CrossRef] [PubMed]

193. Hardaway, J.A.; Crowley, N.A.; Bulik, C.M.; Kash, T.L. Integrated circuits and molecular components for stress and feeding: Implications for eating disorders. Genes Brain Behav. 2015, 14, 85-97. [CrossRef] [PubMed]

194. Lo Sauro, C.; Ravaldi, C.; Cabras, P.L.; Faravelli, C.; Ricca, V. Stress, hypothalamic-pituitary-adrenal axis and eating disorders. Neuropsychobiology 2008, 57, 95-115. [CrossRef] [PubMed]

195. Jahng, J.W. An animal model of eating disorders associated with stressful experience in early life. Horm. Behav. 2011, 59, 213-220. [CrossRef] [PubMed]

196. Hagan, M.M.; Wauford, P.K.; Chandler, P.C.; Jarrett, L.A.; Rybak, R.J.; Blackburn, K. A new animal model of binge eating: Key synergistic role of past caloric restriction and stress. Physiol. Behav. 2002, 77, 45-54. [CrossRef]

197. Boggiano, M.M.; Chandler, P.C. Binge eating in rats produced by combining dieting with stress. Curr. Protoc. Neurosci. 2006. [CrossRef]

198. Razzoli, M.; Sanghez, V.; Bartolomucci, A. Chronic subordination stress induces hyperphagia and disrupts eating behavior in mice modeling binge-eating-like disorder. Front. Nutr. 2015, 1. [CrossRef] [PubMed]

199. Calvez, J.; de Avila, C.; Guevremont, G.; Timofeeva, E. Stress differentially regulates brain expression of corticotropin-releasing factor in binge-like eating prone and resistant female rats. Appetite 2016, 107, 585-595. [CrossRef] [PubMed]

200. Calvez, J.; Timofeeva, E. Behavioral and hormonal responses to stress in binge-like eating prone female rats. Physiol. Behav. 2016, 157, 28-38. [CrossRef] [PubMed]

201. Micioni Di Bonaventura, M.V.; Ciccocioppo, R.; Romano, A.; Bossert, J.M.; Rice, K.C.; Ubaldi, M.; St Laurent, R.; Gaetani, S.; Massi, M.; Shaham, Y.; et al. Role of bed nucleus of the stria terminalis corticotrophin-releasing factor receptors in frustration stress-induced binge-like palatable food consumption in female rats with a history of food restriction. J. Neurosci. 2014, 34, 11316-11324. [CrossRef] [PubMed]

202. Micioni Di Bonaventura, M.V.; Ubaldi, M.; Giusepponi, M.E.; Rice, K.C.; Massi, M.; Ciccocioppo, R.; Cifani, C. Hypothalamic CRF1 receptor mechanisms are not sufficient to account for binge-like palatable food consumption in female rats. Int. J. Eat. Disord. 2017, 50, 1194-1204. [CrossRef] [PubMed]

203. Contreras, C.; Novelle, M.G.; Leis, R.; Dieguez, C.; Skrede, S.; Lopez, M. Effects of neonatal programming on hypothalamic mechanisms controlling energy balance. Horm. Metab. Res. 2013, 45, 935-944. [CrossRef] [PubMed]

204. Schroeder, M.; Jakovcevski, M.; Polacheck, T.; Lebow, M.; Drori, Y.; Engel, M.; Ben-Dor, S.; Chen, A. A methyl-balanced diet prevents CRF-induced prenatal stress-triggered predisposition to binge eating-like phenotype. Cell Metab. 2017, 25, 1269-1281. [CrossRef] [PubMed]

205. Avena, N.M. Examining the addictive-like properties of binge eating using an animal model of sugar dependence. Exp. Clin. Psychopharmacol. 2007, 15, 481-491. [CrossRef] [PubMed]

206. Rada, P.; Avena, N.M.; Hoebel, B.G. Daily bingeing on sugar repeatedly releases dopamine in the accumbens shell. Neuroscience 2005, 134, 737-744. [CrossRef] [PubMed]

207. Cottone, P.; Sabino, V.; Steardo, L.; Zorrilla, E.P. Consummatory, anxiety-related and metabolic adaptations in female rats with alternating access to preferred food. Psychoneuroendocrinology 2009, 34, 38-49. [CrossRef] [PubMed]

208. Iemolo, A.; Valenza, M.; Tozier, L.; Knapp, C.M.; Kornetsky, C.; Steardo, L.; Sabino, V.; Cottone, P. Withdrawal from chronic, intermittent access to a highly palatable food induces depressive-like behavior in compulsive eating rats. Behav. Pharmacol. 2012, 23, 593-602. [CrossRef] [PubMed]

209. Mathes, C.M.; Ferrara, M.; Rowland, N.E. Cannabinoid-1 receptor antagonists reduce caloric intake by decreasing palatable diet selection in a novel dessert protocol in female rats. Am. J. Physiol. Regul. Integr. Comp. Physiol. 2008, 295, R67-R75. [CrossRef] [PubMed]

210. Parylak, S.L.; Cottone, P.; Sabino, V.; Rice, K.C.; Zorrilla, E.P. Effects of CB1 and CRF1 receptor antagonists on binge-like eating in rats with limited access to a sweet fat diet: Lack of withdrawal-like responses. Physiol. Behav. 2012, 107, 231-242. [CrossRef] [PubMed] 
211. Shariff, M.; Klenowski, P.; Morgan, M.; Patkar, O.; Mu, E.; Bellingham, M.; Belmer, A.; Bartlett, S.E. Binge-like sucrose consumption reduces the dendritic length and complexity of principal neurons in the adolescent rat basolateral amygdala. PLoS ONE 2017, 12, e0183063. [CrossRef] [PubMed]

212. Murray, S.M.; Tulloch, A.J.; Chen, E.Y.; Avena, N.M. Insights revealed by rodent models of sugar binge eating. CNS Spectr. 2015, 20, 530-536. [CrossRef] [PubMed]

213. Yasoshima, Y.; Shimura, T. A mouse model for binge-like sucrose overconsumption: Contribution of enhanced motivation for sweetener consumption. Physiol. Behav. 2015, 138, 154-164. [CrossRef] [PubMed]

214. Corwin, R.L.; Wojnicki, F.H. Binge eating in rats with limited access to vegetable shortening. Curr. Protoc. Neurosci. 2006. [CrossRef]

215. Corwin, R.L.; Avena, N.M.; Boggiano, M.M. Feeding and reward: Perspectives from three rat models of binge eating. Physiol. Behav. 2011, 104, 87-97. [CrossRef] [PubMed]

216. Liang, N.C.; Hajnal, A.; Norgren, R. Sham feeding corn oil increases accumbens dopamine in the rat. Am. J. Physiol. Regul. Integr. Comp. Physiol. 2006, 291, R1236-R1239. [CrossRef] [PubMed]

217. Corwin, R.L.; Wojnicki, F.H. Baclofen, raclopride, and naltrexone differentially affect intake of fat and sucrose under limited access conditions. Behav. Pharmacol. 2009, 20, 537-548. [CrossRef] [PubMed]

218. Rao, R.E.; Wojnicki, F.H.; Coupland, J.; Ghosh, S.; Corwin, R.L. Baclofen, raclopride, and naltrexone differentially reduce solid fat emulsion intake under limited access conditions. Pharmacol. Biochem. Behav. 2008, 89, 581-590. [CrossRef] [PubMed]

219. Berner, L.A.; Bocarsly, M.E.; Hoebel, B.G.; Avena, N.M. Baclofen suppresses binge eating of pure fat but not a sugar-rich or sweet-fat diet. Behav. Pharmacol. 2009, 20, 631-634. [CrossRef] [PubMed]

220. Wong, K.J.; Wojnicki, F.H.; Corwin, R.L. Baclofen, raclopride, and naltrexone differentially affect intake of fat/sucrose mixtures under limited access conditions. Pharmacol. Biochem. Behav. 2009, 92, 528-536. [CrossRef] [PubMed]

221. Puhl, M.D.; Cason, A.M.; Wojnicki, F.H.; Corwin, R.L.; Grigson, P.S. A history of bingeing on fat enhances cocaine seeking and taking. Behav. Neurosci. 2011, 125, 930-942. [CrossRef] [PubMed]

222. Bocarsly, M.E.; Berner, L.A.; Hoebel, B.G.; Avena, N.M. Rats that binge eat fat-rich food do not show somatic signs or anxiety associated with opiate-like withdrawal: Implications for nutrient-specific food addiction behaviors. Physiol. Behav. 2011, 104, 865-872. [CrossRef] [PubMed]

223. Teegarden, S.L.; Bale, T.L. Effects of stress on dietary preference and intake are dependent on access and stress sensitivity. Physiol. Behav. 2008, 93, 713-723. [CrossRef] [PubMed]

224. Teegarden, S.L.; Bale, T.L. Decreases in dietary preference produce increased emotionality and risk for dietary relapse. Biol. Psychiatry 2007, 61, 1021-1029. [CrossRef] [PubMed]

225. Heo, Y.A.; Duggan, S.T. Lisdexamfetamine: A review in binge eating disorder. CNS Drugs 2017, 31, $1015-1022$. [CrossRef] [PubMed]

226. Vickers, S.P.; Hackett, D.; Murray, F.; Hutson, P.H.; Heal, D.J. Effects of lisdexamfetamine in a rat model of binge-eating. J. Psychopharmacol. 2015, 29, 1290-1307. [CrossRef] [PubMed]

227. Heal, D.J.; Goddard, S.; Brammer, R.J.; Hutson, P.H.; Vickers, S.P. Lisdexamfetamine reduces the compulsive and perseverative behaviour of binge-eating rats in a novel food reward/punished responding conflict model. J. Psychopharmacol. 2016, 30, 662-675. [CrossRef] [PubMed]

228. Vickers, S.P.; Goddard, S.; Brammer, R.J.; Hutson, P.H.; Heal, D.J. Investigation of impulsivity in binge-eating rats in a delay-discounting task and its prevention by the D-amphetamine prodrug, lisdexamfetamine. J. Psychopharmacol. 2017, 31, 784-797. [CrossRef] [PubMed]

229. Bello, N.T.; Hajnal, A. Acute methylphenidate treatments reduce sucrose intake in restricted-fed bingeing rats. Brain Res. Bull. 2006, 70, 422-429. [CrossRef] [PubMed]

230. Bocarsly, M.E.; Hoebel, B.G.; Paredes, D.; von Loga, I.; Murray, S.M.; Wang, M.; Arolfo, M.P.; Yao, L.; Diamond, I.; Avena, N.M. GS 455534 selectively suppresses binge eating of palatable food and attenuates dopamine release in the accumbens of sugar-bingeing rats. Behav. Pharmacol. 2014, 25, 147-157. [CrossRef] [PubMed]

231. Feltmann, K.; Giuliano, C.; Everitt, B.J.; Steensland, P.; Alsio, J. The effects of the monoamine stabilizer (-)-OSU6162 on binge-like eating and cue-controlled food-seeking behavior in rats. Neuropsychopharmacology 2017. [CrossRef] [PubMed] 
232. Cifani, C.; Polidori, C.; Melotto, S.; Ciccocioppo, R.; Massi, M. A preclinical model of binge eating elicited by yo-yo dieting and stressful exposure to food: Effect of sibutramine, fluoxetine, topiramate, and midazolam. Psychopharmacology 2009, 204, 113-125. [CrossRef] [PubMed]

233. Ferragud, A.; Howell, A.D.; Moore, C.F.; Ta, T.L.; Hoener, M.C.; Sabino, V.; Cottone, P. The trace amine-associated receptor 1 agonist RO5256390 blocks compulsive, binge-like eating in rats. Neuropsychopharmacology 2017, 42, 1458-1470. [CrossRef] [PubMed]

234. Ignar, D.M.; Goetz, A.S.; Noble, K.N.; Carballo, L.H.; Stroup, A.E.; Fisher, J.C.; Boucheron, J.A.; Brainard, T.A.; Larkin, A.L.; Epperly, A.H.; et al. Regulation of ingestive behaviors in the rat by GSK1521498, a novel micro-opioid receptor-selective inverse agonist. J. Pharmacol. Exp. Ther. 2011, 339, 24-34. [CrossRef] [PubMed]

235. Piccoli, L.; Micioni Di Bonaventura, M.V.; Cifani, C.; Costantini, V.J.; Massagrande, M.; Montanari, D.; Martinelli, P.; Antolini, M.; Ciccocioppo, R.; Massi, M.; et al. Role of orexin-1 receptor mechanisms on compulsive food consumption in a model of binge eating in female rats. Neuropsychopharmacology 2012, 37, 1999-2011. [CrossRef] [PubMed]

236. Alcaraz-Iborra, M.; Carvajal, F.; Lerma-Cabrera, J.M.; Valor, L.M.; Cubero, I. Binge-like consumption of caloric and non-caloric palatable substances in ad libitum-fed C57BL/6J mice: Pharmacological and molecular evidence of orexin involvement. Behav. Brain Res. 2014, 272, 93-99. [CrossRef] [PubMed]

237. Buda-Levin, A.; Wojnicki, F.H.; Corwin, R.L. Baclofen reduces fat intake under binge-type conditions. Physiol. Behav. 2005, 86, 176-184. [CrossRef] [PubMed]

238. Micioni Di Bonaventura, M.V.; Ubaldi, M.; Liberati, S.; Ciccocioppo, R.; Massi, M.; Cifani, C. Caloric restriction increases the sensitivity to the hyperphagic effect of nociceptin/orphanin fq limiting its ability to reduce binge eating in female rats. Psychopharmacology 2013, 228, 53-63. [CrossRef] [PubMed]

239. Statnick, M.A.; Chen, Y.; Ansonoff, M.; Witkin, J.M.; Rorick-Kehn, L.; Suter, T.M.; Song, M.; Hu, C.; Lafuente, C.; Jimenez, A.; et al. A novel nociceptin receptor antagonist LY2940094 inhibits excessive feeding behavior in rodents: A possible mechanism for the treatment of binge eating disorder. J. Pharmacol. Exp. Ther. 2016, 356, 493-502. [CrossRef] [PubMed]

240. Hardaway, J.A.; Jensen, J.; Kim, M.; Mazzone, C.M.; Sugam, J.A.; Diberto, J.F.; Lowery-Gionta, E.G.; Hwa, L.S.; Pleil, K.E.; Bulik, C.M.; et al. Nociceptin receptor antagonist SB 612111 decreases high fat diet binge eating. Behav. Brain Res. 2016, 307, 25-34. [CrossRef] [PubMed]

241. Cottone, P.; Wang, X.; Park, J.W.; Valenza, M.; Blasio, A.; Kwak, J.; Iyer, M.R.; Steardo, L.; Rice, K.C.; Hayashi, T.; et al. Antagonism of sigma-1 receptors blocks compulsive-like eating. Neuropsychopharmacology 2012, 37, 2593-2604. [CrossRef] [PubMed]

242. Steward, T.; Menchon, J.M.; Jimenez-Murcia, S.; Soriano-Mas, C.; Fernandez-Aranda, F. Neural network alterations across eating disorders: A narrative review of fMRI studies. Curr. Neuropharmacol. 2017. [CrossRef] [PubMed]

(C) 2018 by the authors. Licensee MDPI, Basel, Switzerland. This article is an open access article distributed under the terms and conditions of the Creative Commons Attribution (CC BY) license (http:/ / creativecommons.org/licenses/by/4.0/). 